\title{
DILEMAS DA TRADUÇÃO DO MARXISMO NA PERIFERIA: ANTONIO GRAMSCI E OS FUNDAMENTOS DOS SUBALTERN STUDIES
}

\author{
Camila Góes \\ é bolsista Fapesp e doutoranda em Ciência Política na Unicamp. Campinas, SP. Brasil. \\ E-mail:<camilagoes2905@gmail.com> \\ http://dx.doi.org/10.1590/0102-299351/102
}

Questionando a suposição de que a vida intelectual seria espontaneamente internacional, Bourdieu (2002), em Les conditions sociales de la circulation internationale des idées, abordou o processo de importação e exportação de ideias entre contextos nacionais diversos. Ao apontar tendências existentes nessas trocas, o autor indicou alguns dos desafios a ser enfrentados na conformação de uma vida intelectual "verdadeiramente" internacional (Bourdieu, 2002, p. 3). Para o sociólogo francês, as trocas internacionais estariam sujeitas a certo número de fatores estruturais, o que poderia gerar uma série de mal-entendidos. Um deles derivaria do fato de textos circularem sem seus contextos, que não são importados do campo de produção, o que faz com que sejam inseridos e reinterpretados de acordo com a estrutura de outro campo, o de recepção.

Para os fins deste artigo, interessa ressaltar a afirmação bourdieusiana de que as condições de produção de um texto não são as mesmas de sua recepção. Ou seja, as intenções originárias do autor, passíveis de compreensão em seu contexto, podem ser parcialmente perdidas ou mesmo se 
tornarem inteligíveis a partir do uso de seu texto em outro contexto, no qual adquire nova função e significado. Nessa operação, o risco de imputar aos autores e obras intenções e significados que jamais tiveram e que nem poderiam ter tido em seus contextos originais de produção, está sempre presente.

Essa era uma das preocupações centrais de Quentin Skinner, expoente da chamada "escola de Cambridge". Skinner (1969) não estava especialmente preocupado com a circulação de ideias, mas com a compreensão das obras em seus contextos linguísticos próprios, nos quais seria possível desvendar as verdadeiras intenções dos autores. De modo geral, suas proposições metodológicas procuravam evitar o anacronismo, considerado um dos erros mais graves em que um historiador do pensamento poderia incorrer. Seria necessário buscar não só a intenção do autor de "ser entendido" como também a intenção do "que deveria 300 ser" entendido pelo leitor.

Mas como lidar com a compreensão de textos quando estes passam a ser empregados em outros contextos nacionais? Nesse caso, não basta nos atentarmos à intenção de quem produziu o texto, mas também às intenções dos que realizam sua recepção. Para pensar esse processo, que Bourdieu chamou de "importação-exportação" de ideias, a metáfora da tradução e a ideia de nacionalização do pensamento podem ser profícuas. Perseguindo essas questões, nos concentraremos na recepção do pensamento de Antonio Gramsci na Índia realizada pelos Subaltern studies. De modo subjacente, a recepção latino-americana será destacada de modo a lançar luz sobre alguns aspectos da circulação internacional de suas ideias e sobre os dilemas próprios da migração do marxismo a contextos periféricos. ${ }^{1}$

1 O próprio Gramsci sugeriu, desde os textos pré-carcerários, a distinção entre Estados capitalistas avançados e Estados capitalistas periféricos. Os primeiros se caracterizariam por ter uma classe dominante com reservas políticas e 
A existência ou não de um pensamento marxista latino-americano, por exemplo, foi tratada por Bernardo Ricupero $(2000)^{2}$ e por Luis Tapia Mealla $(2002)^{3}$ a partir da categoria de "nacionalização do marxismo". Ricupero (2000, p. 29) definiu esse fenômeno como a "capacidade de traduzir" a abordagem da teoria marxista às "condições específicas de uma determinada experiência histórico-social”. Mealla (2002, p. 327), por sua vez, entendeu a nacionalização do

organizativas, de modo que nem mesmo crises econômicas gravíssimas teriam repercussões imediatas no campo político. Nos segundos, as forças estatais seriam menos eficientes, mas ocorreria um fenômeno importante: "entre o proletariado e o capitalismo, estende-se um amplo estrato de classes intermediárias" (Gramsci, 2004, p. 379). A partir dessas sugestões, Portantiero (1977, pp. 65-69) considerava ser possível reconhecer dois grandes tipos de sociedades ocidentais, definidas principalmente pelas características que assume a articulação entre sociedade e Estado. Nesse sentido, alguns países da América Latina, como a Argentina e o Brasil, tendo em vista seus tipos de desenvolvimento, poderiam ser entendidos como "Ocidente" periférico e tardio.

2 Para Ricupero, a obra de Caio Prado Jr. seria o exemplo desse fenômeno no Brasil. Tendo traduzido o modo de abordagem da teoria marxista às condições da experiência histórico-social específica brasileira, o historiador paulistano havia proporcionado assim uma capacidade de reflexão original sobre elas (Ricupero, 2000, p. 29). Como exemplares dessa perspectiva, ao lado do autor de Formação do Brasil contemporâneo estariam Gramsci e Mariátegui. Dando continuidade a essa reflexão e seguindo a sugestão de Ricupero, André Kaysel realizou, em Dois encontros entre o Marxismo e a América Latina (2012), estudo sistemático da obra de Caio Prado e Mariátegui. O livro também tem como ponto de partida a questão das dificuldades encontradas na "aclimatação" das referências ideológicas vindas das antigas metrópoles quando empregadas ao novo contexto "dependente" e "periférico". O grande problema, para Kaysel, teria sido sempre conceber uma política revolucionária de acordo com a realidade latino-americana. É nesse sentido que os dois autores em questão se aproximariam - "tanto o peruano quanto o brasileiro se preocuparam em apropriar-se do materialismo histórico e dialético de uma forma criativa, que lhes possibilitasse compreender a história de seus países e seus impasses contemporâneos. Esse objetivo comum, e a originalidade das interpretações daí decorrentes, são os primeiros pontos de contato entre esses dois intelectuais de formação e trajetórias tão diversas" (Kaysel, 2012, p. 26; sobre a influência do marxista peruano no ambiente intelectual brasileiro, cf. Pericás, 2010).

${ }^{3}$ Mealla pensava na obra do marxista René Zavaleta, que seria o mais importante exemplo de nacionalização do marxismo na Bolívia. Para delimitar os graus de apropriação e interiorização das teorias ou estratégias cognitivas, Mealla valia-se das ideias marxianas de subsunção formal e subsunção real, abundantes nos textos de Zavaleta, extrapolando-as para os processos de apropriação das teorias gerais e das trocas que introduzem no pensamento e nos resultados consequentes (Mealla, 2002, pp. 327-330). 
marxismo como forma de "apropriação" via "interiorização". Para o marxista boliviano, na medida em que se torna uma concepção de mundo interiorizada, a teoria poderia se converter em forma de pensar o conjunto de relações e experiências da vida cotidiana, refletindo sobre a sociedade em que se localiza. Mealla incluiu a nacionalização e a produção de teoria como parte de um mesmo processo intelectual de “produção de conhecimento local” (Mealla, 2002, p. 326).

Já o argentino Horácio Tarcus recorreu ao conceito de recepção para pensar as ideias de Marx na América Latina. Esse conceito remeteria, segundo argumenta o autor, a um processo maior de produção/difusão intelectual no qual seria necessário discriminar analiticamente produtores, difusores, receptores e consumidores das ideias, ainda que esses processos se confundissem na prática e esses papéis pudessem ser assumidos simultaneamente por um mesmo sujeito (Tarcus, 2007, p. 30). Nesse sentido, para Tarcus, importaria saber como e por que leram Marx, e não se leram "correta" ou "incorretamente". O objetivo seria, portanto, buscar quais leituras de Marx eram possíveis em certas coordenadas geográficas, temporais e sociais - no caso, a Argentina do fim do século XIX (Tarcus, 2007, p. 33).

Pensando questões similares, Bianchi (2016) argumentou que a metáfora da tradução seria a que melhor permitiria pensar o processo de produção das ideias como não sendo simples transferência, nem consumo passivo de informações produzidas em outro contexto (Bianchi, 2016, p. 2). Ao contrário, implicaria sempre numa negociação entre diferentes culturas, num processo no qual o resultado não poderia estar necessariamente previsto no original (Bianchi, 2016, p. 9). O potencial da metáfora residiria na possibilidade de apreender significados que têm lugar durante o complexo processo de emissão e recepção cultural (Bianchi, 2016, p. 10). 
Também através da metáfora da tradução, Martin Cortés, em Un nuevo marxismo para América Latina (2015), refletiu sobre as seguintes questões:

Se o marxismo é um universo teórico produzido a partir da experiência do mundo europeu, em que sentido pode ser frutífero para uma crítica de outras geografias? Por outro lado, já que na história da região geralmente se encontra em um mundo paralelo ao do movimento popular, antes de vir junto com ele, por que insistir em apoiar a díade "marxismo latino-americano"? (Cortés, 2015, p. 16).

Cortés respondeu a essas questões afirmando que seria possível pensar um marxismo latino-americano desde que existisse exercício de tradução capaz de articular de maneira orgânica a vocação universal indicada na primeira pergunta com os dilemas específicos que apresentava a segunda. ${ }^{4}$ Esse caráter orgânico da tradução remetia à produção de novidade teórica, resultado imprevisto sobre o qual afirmava Bianchi (2016), contraposto a exercícios de mera aplicação de conceitos já constituídos.

Esse conjunto de problemas já havia sido enunciado nos escritos carcerários gramscianos. ${ }^{5}$ Para Gramsci, a tradutibilidade pressuporia determinada etapa da civilização de expressão cultural "fundamentalmente" idêntica, mesmo que com linguagem historicamente diversa, determinada

${ }^{4}$ Pensando o caso argentino, Cortés indicou a obra de Aricó como exercício de tradução em sentido gramsciano - e é através dessa ótica que propõe entender também suas empreitadas intelectuais, em especial a revista Pasado y Presente. O intelectual argentino, argumentou Cortés (2010, pp. 151-152), propunha não uma aplicação, mas um exercício permanente de confrontação com os problemas de sua época e lugar. No livro Un nuevo marxismo para América Latina (2015) Cortés busca demonstrar que os escritos e iniciativas editoriais de Aricó "podem ser entendidos como uma profunda indagação acerca do tipo de marxismo que resultaria produtivo na América Latina" (Cortés, 2015, p. 17, grifos do autor).

${ }_{5}$ Para saber mais a respeito, cf. Tosel (1981), Frosini (2003), Boothman (2004) e Ives (2004). 
pela tradição particular de cada cultura nacional e de cada sistema filosófico (Gramsci, 1975, Q 11, §47, p. 1468). ${ }^{6}$ O marxista sardo entendia que a tradução era possível devido a um mesmo "fundo" essencial decorrente de um progresso real da civilização e graças à colaboração de todos os povos, por "impulsos" nacionais (Gramsci, 1975, Q 11, $\$ 47$, p. 1470). Em suma, o esforço de traduzir uma linguagem a uma realidade cultural e específica excluiria toda possibilidade de aplicação ou perfeição. "Que língua é exatamente traduzível em outra? Que palavra singular é exatamente traduzível em outra língua?”, questionava Gramsci (Gramsci, 1975, Q 11, §47, p. 1470).

É nesse sentido que propomos entender a produção subalternista como uma tentativa de traduzir o marxismo à realidade indiana. Em oposição à ideia de "aplicação", entendemos que há entre os subalternistas indianos, como veremos a seguir, a produção de algo novo. De modo par304 ticular, é possível afirmar mesmo que o encontro de Gramsci com determinadas culturas nacionais tenha possuído como característica geral a criação de novos projetos políticos e uma nova ideia da política (Vacca, 2009, p. 13).

Essa hipótese é de Giuseppe Vacca, que afirma ter sido assim "na Itália do pós-guerra", "na Índia, tanto antes como depois do nascimento dos Subaltern Studies" e também "na América Latina, onde em alguns países, como na Argentina e no Brasil [...] teve um papel fundamental na renovação da história política dos grupos intelectuais, em favor das "revoluções democráticas'” (Vacca, 2009, p. 13). O pensamento de Gramsci parece ter indicado um caminho frutífero, nesses contextos, para a difícil tarefa de tradução do marxismo na periferia do capitalismo. Exploraremos, a seguir, alguns

${ }^{6}$ Utilizaremos a edição crítica dos Cadernos do cárcere, organizada por Valentino Gerratana e publicada em 1975 na Itália. Citaremos da seguinte forma: Q. "X", para o número do Caderno, § "Y", para o parágrafo, e p. "Z" para a página na referida edição. Todas as traduções do italiano e inglês serão realizadas pela autora. 
aspectos desse processo, em particular através da produção dos Subaltern Studies ao longo dos anos 1980. Em menor grau, buscaremos lançar luz à experiência latino-americana, com os gramscianos brasileiros e argentinos, de modo a destacar alguns dos dilemas da tradução do marxismo na periferia e os caminhos encontrados para sua solução a partir das indicações gramscianas.

\section{0 marxismo e os povos "sem história"}

As dificuldades inerentes à tradução do pensamento marxista em contextos periféricos foram demonstradas desde Marx e Engels que, por vezes, adotaram em seus escritos uma visada eurocêntrica. Embora seja mais evidente em Engels do que em Marx, o que se comprova nas repetidas vezes nas quais fez referência aos "povos sem história", essa visada não deixava de se fazer presente também "no autor d'O Capital" (Bianchi, 2010, p. 178).7

A proposição de que a Índia seria uma terra desprovida de história, indicada por Hegel em inícios do século XIX ${ }^{8}$

\footnotetext{
7 Os primeiros artigos de Marx e Engels (cf. Marx, 1978; Ahmad, 2002) sobre o contexto indiano apresentaram maior inclinação a amplas generalizações, inexatidões e desinformações. Marx sabia pouco sobre a Índia quando começou a escrever, o que fica claro quando se atenta ao fato de que o autor pensava que todos os direitos de posse sobre a região agrícola indiana eram de estrangeiros mesmo antes da dominação britânica. Essa ideia foi propagada pelas autoridades inglesas, que, como novos governantes daquele país, buscaram convencer a população indiana de que os britânicos possuíam naturalmente direito sobre a terra. Apenas quatro anos depois, em 1857, quando começou a escrever a segunda seção de artigos sobre a Índia, Marx percebeu que esse fato poderia ser entendido no máximo como espécie de "ficção legal", embora tenha permanecido sem compreender completamente o complexo sistema agrícola da Índia pré-britânica. O autor só adquiriu algum senso de tamanha complexidade muito depois, quando a Índia passou a figurar em seus escritos apenas como caso comparativo (Ahmad, 2002, pp. 16-17).

8 Em A Razão na história, Hegel explicava que no alemão, a palavra história combinava tanto o lado objetivo quanto o subjetivo, "ao mesmo tempo historia rerum gestarum e res gestae: os acontecimentos e a narração dos acontecimentos" (Hegel, 2001, p. 111). Para o filósofo alemão, o tema adequado à prosa da história seria apresentado pelo Estado, que a criaria consigo. Isso porque uma comunidade que adquire existência estável e se eleva a Estado exige mais do que simples mandatos
} 
não influenciou apenas Marx e Engels, mas boa parte dos críticos ingleses da época (Lal, 2001, p. 135). ${ }^{9}$ No começo do século posterior, Edward Thompson (1926), pai de E. P. Thompson, afirmou que os indianos raramente foram capazes de mostrar "qualquer habilidade crítica" e, com a certeza de que jamais se tornariam adeptos do ofício histórico, acrescentou que dificilmente seriam capazes de desarticular o relato da conexão britânica com a Índia (Thompson, 1926, pp. 27-28).

Somente duas décadas depois, em 1947, a colonização britânica na Índia teria fim. Desde então, teve início o desenvolvimento da "história moderna indiana" como resultado de pesquisas não só de universidades da Índia, mas também da Inglaterra, dos Estados Unidos e da Austrália (Chakrabarty, 2000, p. 10). Contrapondo-se ao diagnóstico do pai de E. P. Thompson, Ranajit Guha (1997, p. 1) ${ }^{10}$ afir-

subjetivos de governo - exige regras, leis, normas universais e universalmente válidas. Desse modo, a comunidade produz e está interessada em um registro inteligente e preciso, com resultados duradouros, de suas ações e acontecimentos. Nesse sentido, afirmava Hegel: "somente em um Estado com a consciência das leis existem ações claras e essa consciência é clara o suficiente para fazer com que os registros sejam possíveis e desejáveis. Impressiona a todos os que conhecem os tesouros da literatura indiana o fato de que este país, tão rico em produtos intelectuais de grande profundidade, não tenha uma história” (Hegel, 2001, p. 113). Importante destacar que, para Hegel, não eram só os indianos que não possuíam história. Também os eslavos, americanos, africanos etc.

9 Macaulay e James Mill estavam inteiramente convencidos de que os indianos eram incapazes de escrever história. Para Hegel (2001, p. 113), mesmo com esplêndidos trabalhos de poesia e antigos códigos de leis, na Índia o desejo de organização havia se petrificado em distinções naturais de casta. As leis, embora dissessem respeito a direitos civis, os faziam dependentes dessas distinções naturais. $\mathrm{O}$ filósofo concluía, dessa forma, que "uma fantasia profunda e impetuosa" vagueava por toda a região e que, para poder criar sua história, a Índia precisaria de um "objetivo dentro da realidade e, ao mesmo tempo, de muita liberdade" (Hegel, 2001, p. 113).

${ }^{10}$ Ranajit Guha, nascido em 1922, é um historiador indiano que editou os primeiros seis volumes da série Subaltern Studies: writings on South Asian History (I, II, III, IV, V, VI) de 1982 a 1989. Suas publicações incluem A rule of property for Bengal: an essay on the idea of permanent settlement (1963), Elementary aspects of peasant insurgency in colonial India (1999 [1983]), e Dominance without hegemony: history and power in colonial India (1997). 
mou que a "apropriação do passado" fora a única batalha que a Inglaterra jamais havia vencido sobre o povo indiano. Sob sua liderança, o surgimento dos Subaltern Studies consistiu num dos principais desdobramentos desse contexto de inovação teórica da história social e política indiana (Chandavarkar, 2000, p. 181). ${ }^{11}$ Neste artigo, nos deteremos na primeira fase do grupo, marcada pela liderança de Guha e pela influência do pensamento de Antonio Gramsci. ${ }^{12}$ Com isso, buscaremos examinar também o modo como a própria obra de Marx foi repensada no projeto subalternista em dois aspectos fundamentais: numa perspectiva global, particularmente em relação ao colonialismo e numa exploração dos temas da cultura e da hegemonia/subalternidade no lugar da então preocupação primária com a economia política.

Ao contrário de Hegel, para Gramsci não haveria "povos sem história”, mas grupos sociais que se mantiveram "às margens da história”. O reconhecimento dessa ausência de representação do subalterno esteve presente como base de sua análise da Itália, marcada pela Questão Meridional, em termos da relação Sul e Norte, camponeses e operários. Também a ideia de "revolução passiva", como foi empregada nos Cadernos, sugeria uma ordem de reflexão análoga, a qual fez a Itália ser reconhecida como "não-França”, já que, diferente da Revolução de 1789, não havia coincidência de povo e nação no projeto do Risorgimento.

11 Para James Scott, junto com a "teoria da dependência" latino-americana, os Subaltern Studies foram a importação intelectual vinda do Sul que teve maior influência sobre a conduta da história e das ciências sociais acerca dos movimentos populares (Scott, 1999, p. x).

12 Soma-se ainda a influência no coletivo indiano de pensadores pós-estruturalistas, como Michel Foucault e Jacques Derrida. A publicação do Selected Subaltern Studies em 1988, com prefácio assinado por Edward Said, coincide com bifurcação interna do grupo, assim como com a gênese do corpo da literatura geralmente conhecida como "teoria pós-colonial" (Chaturvedi, 2000, p. xii). 
A ideia, no caso dos subalternistas, seria instituir a Índia como "não-Europa". Nessa referência, o projeto adotou o paradigma da história "que vinha de baixo" para contestar a história da "elite" e de certo tipo de marxismo ortodoxo, de fórmulas rígidas. Os Subaltern Studies mantiveram distância, ademais, dos grupos de intelectuais marxistas tradicionais e de militantes comunistas do período. O partido comunista indiano havia cindido em 1964, dando origem ao Partido Comunista Indiano (PCI), alinhado aos interesses soviéticos, e ao Partido Comunista Indiano Marxista (PCIM), de orientação maoísta. Nenhum havia estabelecido Gramsci enquanto influência em seus programas políticos, bem como não conheciam sua vida ou sua obra até então.

"Aos olhos dos Subaltern Studies", ambos os partidos representariam uma "extensão liberal de esquerda da elite que estava no poder" (Guha, 1997, p. 32). Segundo o olhar retrospectivo de Guha, isso não fez com que os Subaltern Studies se entendessem como "apolíticos ou anticomunistas". Ao contrário, na "tentativa de elaborar uma crítica radical ao colonialismo e à presença colonialista que permaneceu no estudo da história e da sociedade da Ásia meridional”, consideravam-se "propriamente marxistas" e se opunham-se aos "dois partidos comunistas oficiais pelo uso oportunista e dogmático do marxismo que faziam” (Guha, 1997, p. 32).

O grupo do qual provém Guha - que já havia tido carreira intelectual e política marcada por difíceis relações com todos os considerados "grandes" do marxismo indiano dos anos de 1950 e $1960^{13}$ - surgiu em meio a esse ambiente político, no final da década de 1970, em torno do Centro

13 Depois de intenso período de militância política e sindical, Guha sai do Partido Comunista Indiano em 1956 e passa a se dedicar à carreira acadêmica, tendo se transferido para a Inglaterra nos anos 1960 para lecionar na Universidade de Sussex. 
de Estudos de Ciências Sociais (CSSC) de Calcutá. ${ }^{14}$ Sob sua decisiva influência, reuniram-se os principais intelectuais que compuseram e fundaram os Subaltern Studies. ${ }^{15}$

É interessante notar que essa posição crítica ao "marxismo oficial" foi uma característica presente também entre os principais gramscianos argentinos e brasileiros que, como os indianos, optaram por organizar coletivos editoriais para polemizar com as mais importantes vertentes nacionais e intelectuais de esquerda. Na Argentina e no Brasil, como no caso das revistas Pasado y Presente e Presença, que veremos adiante, o pensamento de Gramsci estimulou a conformação de centros de elaboração cultural relativamente autônomos das estruturas partidárias como ponto de convergência entre intelectuais comunistas e os que provinham de outros setores da esquerda.

Esse movimento teórico e político concatenado com projetos editoriais foi ainda mais amplo e não se restringiu aos ambientes periféricos. Em English Questions, Perry Anderson (1992) explicitou um processo análogo em meio

14 Despontados em meio acadêmico, um dos importantes fatores para considerar nas origens intelectuais dos Subaltern Studies no que se refere à apropriação de conceitos marxistas, e em especial de Antonio Gramsci, deve-se ao papel desempenhado por Susobhan Sarkar. Foi Sarkar quem forneceu a primeira recepção abrangente de Gramsci em toda Índia. O historiador de Bengali lecionou no Presidence College de Calcutá quando Ranajit Guha era ainda aluno e estabeleceu, assim, seu primeiro contato com a obra gramsciana. Em fins da década de 1950, momento em que a maioria dos "marxistas ocidentais" não estava familiarizada com Gramsci, Sarkar já havia iniciado a discussão sobre a obra do marxista sardo com seus alunos. Foi nesse mesmo período que Guha se tornou colega de Sarkar no Departamento de História da Universidade de Jadavpur. O interesse de Sarkar por Gramsci persistiu na década seguinte, tendo publicado The thought of Gramsci em 1968. A acessibilidade das traduções para o inglês, nesse período, originou pequeno público literato sobre Gramsci na Índia (Chaturvedi, 2000, p. viii).

15 Entre eles estava Dipesh Chakrabarty, que optou por trabalhar sobre a classe operária indiana; Gyanendra Pandey, que tinha já importante tese sobre os camponeses na Índia do Norte; Shahid Amin, também historiador do campesinato; Gautam Bhadra, que se interessava pela história da transição do Império Mongol para o Império Britânico; e Partha Chatterjee, considerado o mais teórico entre eles, devido à formação com maior ênfase em teoria e filosofia política (Subrahmanyam, 2004, p. 10). 
ao contexto intelectual que rondou as origens da revista marxista britânica New Left Review. A empreitada como um todo, cuja iniciativa Anderson compartilhou com Tom Nairn, devia também sua principal inspiração intelectual a Gramsci, que ainda não era familiar à Inglaterra dos anos 1960. ${ }^{16}$ Anderson afirmou ter encontrado em sua obra dois aspectos centrais que falavam à situação inglesa e que nos parecem fundamentais para a compreensão da fortuna que o marxista sardo encontrou em países tão distantes como estímulo à formação de novos "centros de pesquisa" (Baratta, 2009). Além de ter sido o primeiro marxista a traçar as características nacionais de sua própria sociedade capitalista em suas formas particulares, Gramsci teria sido também o primeiro revolucionário a apreender a necessidade de estratégia específica para o socialismo no Ocidente industrializado, pós-advento do sufrágio universal.

No caso da Índia, o encontro com o pensamento de Gramsci produziu uma série de questionamentos em meio ao debate marxista e historiográfico da época. A começar pela visão corrente que entendia a inserção do país ao colonialismo em termos de uma mudança do semifeudalismo para o capitalismo, compreendida como inauguração da “politização dos colonizados” (Spivak, 1988, p. 3). Essa interpretação havia sido sugerida até mesmo por Marx e Engels em seus estudos sobre o país, ${ }^{17}$ cujo significado era disputado pelos historiadores em duas abordagens distintas (Kaviraj, 1983, p. 27). Para uma, seria possível selecionar nas observações marx-engelsianas diversas proposições empíricas sobre a estrutura das formas sociais na Índia. Nessa

\footnotetext{
16 Tendo pouco dos seus textos traduzidos para o inglês, os Cadernos do cárcere não faziam parte do universo intelectual do ainda pequeno setor da cultura socialista que se definia como marxista - situação que não era peculiar à Inglaterra.

17 Os estudos marx-engelsianos sobre a Índia somaram total de 33 artigos para o jornal New York Daily Tribune (NYDT) - doze em 1853, quinze em 1857 e seis em 1858.
} 
visão, a sociedade indiana tradicional seria vista como uma forma de feudalismo. Para a outra perspectiva, por sua vez, não havia encadeamento lógico por trás das notas episódicas e causais de Marx e Engels sobre o país.

Contrários a ambas as abordagens, os Subaltern Studies realizaram pesquisas historiográficas inspiradas em fontes "heterodoxas" do marxismo e, em especial, do pensamento gramsciano, para enfrentar os desafios postos pelo próprio debate político e intelectual daquele contexto. Parte importante deste esforço estava em realizar uma leitura "historicista" dos fundamentos epistemológicos e metodológicos de Marx que, nos termos de Dipesh Chakrabarty, partia da seguinte premissa:

Mantiveram-se sempre ambiguidades suficientes nos seus postulados [de Marx] de modo a tornar possível a emergência de narrativas históricas "marxistas". Essas narrativas giram em torno do tema da "transição histórica".

A maior parte das histórias do terceiro-mundo são escritas em meio às problemáticas colocadas por esta narrativa da transição, que tem como temas primordiais (mesmo que muitas vezes implícito) os do desenvolvimento, da modernização e do capitalismo (Chakrabarty, 1999, p. 267).

Confluentemente, Partha Chatterjee (1988, p. 387) enfatizou a necessidade de se revisitar a história de ascensão dos Estados nacionais capitalistas no mundo e apresentar os caminhos específicos através dos quais emergiram ao modo de dominação burguesa. Chatterjee estava seguro que até o caso mais clássico revelaria a evolução de um processo político composto por não-linearidades e disjunções, bem como por continuidades e permanências, representando compromissos numerosos com outros modos de exercício do poder e com a sobrevivência de instituições, conceitos e formas de autoridade feudais (Chatterjee, 1988, p. 387). 
A identificação das diferenças específicas na ascensão do modo de domínio do poder burguês, e nos limites desse domínio, seria central para um entendimento histórico dos conflitos de classe nos países capitalistas particulares.

Os subalternistas também se contrapunham à interpretação corrente da história intelectual indiana que reduzia os séculos XIX e XX a uma luta entre forças da "reação" e do "progresso". A abordagem tanto sociológica quanto funcional buscava restringir ideias "tradicionais-conservadoras" e "racionais-modernas" às suas raízes sociais - classes reacionárias e progressistas, respectivamente. Ao mesmo tempo, julgavam a efetividade dessas ideias em termos de suas consequências - ou seja, se promoviam ou não a luta nacional democrática contra a dominação e a exploração colonial. Essas investigações levaram, na maior parte das vezes, a resultados contraditórios, pois como destacou Chatterjee (1998, p. 23): "o nacional não foi sempre secular e moderno, e 312 muitas vezes o popular e democrático foi tradicional e até mesmo fanaticamente anti-moderno".

Ao longo da década de 1980, os subalternistas se empenharam em realizar pesquisas que questionassem essas visões, direcionando crítica severa às formulações da chamada "renascença" indiana do século XIX e início do XX. É nesse sentido que a ida a Gramsci para formular um projeto de pesquisa baseado em pressupostos marxistas adquire significado, pois nos sugere uma implícita leitura de Marx que buscou refletir sobre questões tais quais "como escrever a história?", ou mesmo como "o marxismo pode ser entendido enquanto metodologia histórica?”

Alguns dos caminhos para a solução dessas perguntas foram indicados por Gramsci (1975) em suas notas metodológicas do Caderno 25, intitulado Às margens da história (História dos grupos sociais subalternos). A primeira delas era de que a história das classes subalternas seria necessariamente desagregada e episódica e que existiria na sua atividade 
tendência à unificação, mas essa seria a parte menos aparente e que se mostraria apenas quando a vitória fosse alcançada. A segunda era que as classes subalternas sempre sofreriam a iniciativa da classe dominante e, mesmo quando se rebelassem, estariam em estado de defesa alarmada (Gramsci, 1975, Q25, §2, pp. 2283-2284). Tendo isso em vista, Gramsci concluía que cada traço de iniciativa autônoma da parte dos grupos subalternos deveria, por isso, ser de valor inestimável ao historiador integral. $\mathrm{O}$ marxista italiano refinava ainda sua observação metodológica, afirmando que a unidade histórica das classes dirigentes se daria no Estado. Portanto, as classes subalternas, por definição, não estariam unificadas e não poderiam se unificar enquanto não se tornassem Estado: sua história é uma função desagregada e descontínua da história da sociedade civil e, por isso, da história dos Estados ou grupos de Estados (Gramsci, 1975, Q25, §2, pp. 2287-2288).

Veremos, nas próximas seções, como essas indicações gramscianas foram incorporadas às investigações subalternistas, atingindo resultados inovadores. O problema de fundo que movia o grupo liderado por Guha era a busca por uma abordagem abrangente das condições de existência e atividades subalternas, junto a uma agenda de pesquisa "desviante" à interpretação marxista "oficial". ${ }^{18}$ Contrariamente à forma usual com que o marxismo lidou com a história dos países periféricos, o projeto gramsciano abria a possibilidade de incluir os subalternos indianos na História, baseado na busca por seus traços de autonomia e por possibilidades políticas nos mais variados registros.

Também na América Latina as indicações gramscianas permitiram aproximação maior do marxismo com as especificidades de cada país, na mesma medida em que forçaram

\footnotetext{
18 Agenda que, em fins da década de 1980, extrapolaria os limites do debate historiográfico indiano, chegando aos Estados Unidos por intermédio de Gayatri Spivak.
} 
uma reinterpretação do pensamento marxiano, revelando outras possibilidades. Nas palavras de Richard Morse (2000, p. 98), "é possível que Marx tenha virado Hegel de ponta cabeça", mas não seu julgamento "acerca da condição amorfa e pré-histórica do Novo Mundo ibérico”. Aos latino-americanos, portanto, foi igualmente necessário rastrear esse problema no próprio Marx. José Aricó enfrentou esse desafio no clássico Marx y América Latina (2010), publicado pela primeira vez em 1980. Contemporaneamente a Guha, o argentino propôs "leitura crítica de Marx que, inspirada em seu pensamento" afirmasse "não obstante a necessidade de sua constante experimentação e recomposição teórica e política” (Aricó, 2010, p. 76).

Aricó, bem como os subalternistas, se opôs às interpretações correntes das notas marx-engelsianas sobre a América Latina. Ainda que fossem mais esparsas do que as sobre o mundo asiático, não haveria porque considerá-las apenas 314 como "circunstanciais, contraditórias e fortemente eurocêntricas" (Aricó, 2010, p. 86). Esse esquema interpretativo apagava "diferenças" e expulsava a "história de uma evolução que reconhece períodos, viragens, novos descobrimentos, perspectivas diversas" (Aricó, 2010, p. 86). Para Aricó, interessava primordialmente perguntar desde qual perspectiva Marx considerou essa parte do mundo (Aricó, 2010, p. 83). ${ }^{19}$

Diretamente inspirado nas ideias de Gramsci, Aricó (2010) sugeria que a singularidade latino-americana era a razão mais importante da incompreensão de Marx, e de modo mais amplo, de todo movimento socialista. Para assinalar essa singularidade de nossas formações nacionais, o

\footnotetext{
19 Aricó chegava à conclusão em sua obra que o recurso aos "povos sem história" para se referir ao continente não se tratava de fundamento teórico, mas pertencia melhor ao profícuo e controvertido mundo das alegorias de Marx (Aricó, 2010, p. 149). Mais que ideológica, a noção possuía implicação política, que se fazia presente em seu "exacerbado antibonapartismo", no qual "é possível situar as razões políticas que provocaram a ressureição da noção e esse tipo de escotoma sofrido pelo pensamento marxiano" (Aricó, 2010, p. 150).
} 
marxista argentino recorreu ao conceito gramsciano de revolução passiva. Decorria desse processo nosso "caráter essencialmente estatal" e a rapidez com que, nessa região, as mobilizações de massas foram destruídas e isoladas. Esses seriam os elementos que fizeram da América Latina continente alheio à clássica dicotomia Europa e Ásia "que atravessa a consciência intelectual europeia desde a Ilustração até os nossos dias" (Aricó, 2010, p. 180).

A saída apontada por Aricó para os desafios impostos ao marxismo nesse contexto é muito similar à proposta dos subalternistas indianos. Ecoando os escritos gramscianos, o marxista argentino defendia que:

A introdução de um novo ponto de partida, uma nova perspectiva "desde baixo" dos processos históricos, nos quais a consideração das massas populares, de seus movimentos de constituição e de fragmentação, de suas formas expressivas, de suas vinculações com as elites intelectuais ou políticas, de sua homogeneidade interna, de seus mitos e valores, de seu grau de sujeição ou autonomia, deveria ser reivindicado como o único e verdadeiro critério marxista (Aricó, 2010, p. 181).

Esse argumento estava profundamente conectado aos interesses de pesquisa e ambições políticas do grupo ao qual Aricó pertencia, reunido em torno da revista Pasado y Presente, que abordaremos mais adiante. Alguns anos depois da publicação Marx y América Latina, em 1988, Aricó se propôs exercício similar, agora perscrutando o itinerário de Gramsci na América Latina. Unindo ambas as obras, o intelectual argentino destacou duas entre as categorias essenciais da análise teórica de Gramsci - a criticidade e a historicidade (Aricó, 2014 [1988], p. 108). Ambas teriam sido fundamentais aos gramscianos latino-americanos em sua leitura dos acontecimentos do mundo e na problematização 
com a própria história do marxismo (Aricó, 2014 [1988], p. 108).

São muito variados os "usos de Gramsci" - para recorrer à expressão de Juan Carlos Portantiero (1977) - e também bem diversos seus resultados teóricos e sentidos políticos. ${ }^{20}$ Interessa-nos destacar, de modo especial, aqueles usos que serviram ao propósito de realizar interpretações voltadas às especificidades das formações nacionais periféricas, partindo da visão antidogmática e criativa do marxismo. Entendemos que foi dessa forma que os subalternistas indianos recorreram aos escritos de Gramsci, o que buscaremos demonstrar de forma pormenorizada nas próximas seções. De modo complementar, procuraremos sugerir pontos de encontro com a América Latina, particularmente através das intervenções argentinas e brasileiras.

\section{Por uma história das classes e} grupos sociais subalternos

O desastre dos anos 1940 na Índia - a guerra, a carência, a divisão do subcontinente em dois Estados, o êxodo de centenas de milhares e o conflito sectário de extrema violência - suscitou impacto do qual a população continuou a sofrer ainda por décadas depois da Independência. Entre os pobres das cidades e dos campos, compreendendo também a classe média levada à pobreza, esperava-se sensível

\footnotetext{
${ }^{20}$ Em Los usos de Gramsci, Portantiero ressalta os diversos usos pelos quais a obra de Gramsci foi submetida: "existe, por exemplo, um Gramsci precursor do 'togliattismo', isto é, da política moderada e prudente do comunismo italiano no segundo pós-guerra, considerada por alguns como uma reedição do que levava a cabo a socialdemocracia alemã nas vésperas da primeira guerra mundial [...] outro Gramsci, no extremo oposto, alimenta desde seus 'escritos de juventude' uma visão espontaneísta dos processos revolucionários nos quais o papel da organização política, como instrumento da transformação social, estaria subordinado a um plano quase inexistente" (Portantiero, 1977, p. 11). O autor considera que o fio que outorga unidade a esses fragmentos está dado "por uma concepção sobre a revolução" e é desde esse ponto de vista (e não ao revés) que deveria ser lido o aparato conceitual gramsciano (Portantiero, 1977, p. 17).
} 
melhora de condições com o novo governo independente. No entanto, quando os "chefes coloniais" foram obrigados a sair da Índia e a ocupação inglesa havia finalmente terminado, legiões foram esquecidas e os generais que comandaram o processo de independência trataram rapidamente de "manipular o aparato estatal para assegurar os interesses das classes e da comunidade que representavam" (Guha, 2009, p. 33).

A elite no poder reprimiu cada foco de resistência, recorrendo ao exército, à polícia e às leis, e os críticos tiveram de se contentar em ser oposição no parlamento. Embora essa estratégia tenha funcionado relativamente, não foi o bastante para silenciar a oposição que crescia do lado de fora do congresso. No final dos anos 1960, a miséria havia chegado a tal nível que fez com que uma faísca fosse suficiente para explodir a revolta das massas - essa faísca veio do movimento camponês de Naxalbari. Iniciado como revolta local contra proprietários de terra, logo se tornou sinal de insurreição em pequena escala para outras zonas do campo. Não é menos significativo o fato de que se difundiu também nas zonas urbanas.

O contexto que condicionou as opções teóricas e políticas que levaram ao surgimento do projeto "subalternista" caracterizou-se, fundamentalmente, por esse movimento. A breve experiência do chamado "movimento naxalista" foi derrotada pelas forças conjuntas do Congresso e dos dois partidos comunistas da época, em uma série de operações repressivas que compreenderam o período de 1968 a 1971 (Guha, 2009, p. 32). O que deu força a esse movimento em tão curto espaço de tempo, segundo argumentou Guha, foi o amplo descontentamento com a formação política da nova República Indiana que havia chegado ao poder em 1947.

A força desse movimento nasceu da "desilusão" de duas gerações com a classe governamental e com os elementos dominantes da sociedade. A geração mais velha estava 
desiludida pois os governantes não haviam mantido as promessas de um futuro melhor, utilizadas para mobilizar as massas em busca da Independência quando eram chefes do movimento nacionalista. Já a geração mais jovem estava desiludida, pois os partidos e o governo não souberam lhes garantir um futuro melhor do que a situação que haviam passado ao longo da infância. É também esse duplo descontentamento que trouxe força aos Subaltern Studies, que têm Guha como representante da geração mais velha e outros intelectuais ${ }^{21}$ pertencentes à geração mais jovem.

O projeto subalternista como parte orgânica de seu tempo, partia da premissa de que o fim do domínio colonial não originou nada que substituísse ou modificasse substancialmente seu principal aparato - o Estado. Por isso, quando o poder passou às mãos dos indianos e a miséria do velho regime prosseguiu inalterada, a situação do presente restituiu diretamente seu passado imediato. Essa associação abriu amplo espaço no qual perguntas e preocupações puderam se reunir em torno de temas contíguos do Estado e da sociedade civil. Para ambos os temas, a obra de Gramsci ofereceu contribuição importante.

Na tentativa de entender a distância estabelecida entre o povo e o governo, os Subaltern Studies recorreram à noção de hegemonia. O Estado colonial havia sido conquistado pelos ingleses não através do consenso da população local, mas por meio da força. No entanto, mesmo que tivessem escolhido o temor como princípio fundamental de seu governo, os ingleses compreenderam que, para convencer a elite indiana a sustentar o $R a j$, precisariam recorrer também a diversos meios ideológicos. A estratégia mostrou-se eficiente, visto que o domínio inglês perdurou por quase dois séculos.

21 Ver nota 15. 
Partindo dessa perspectiva, os Subaltern Studies assumiram a tarefa de situar momentos particulares dessa complexa relação em uma configuração geral de poder. Entendia-se não só a desigualdade entre conquistadores ingleses e súditos indianos, mas entre dominantes e dominados também em termos de classe, casta, gênero, geração e assim por diante. Essa variedade de relações, por sua vez, derivaria de uma relação geral de domínio, por coerção e persuasão; e de uma relação de subordinação, por colaboração e resistência:

A reciprocidade de domínio e subordinação é lógica e universal; mas o mesmo não vale para as respectivas cópias constitutivas, que se implicam reciprocamente somente em certas condições, e a saber, de maneira contingente. Como consequência, mais que os conceitos abstratos de domínio e subordinação, são estas condições que exprimem concretamente o dinamismo da experiência histórica em todo seu escorrer e fluir. De fato, são propriamente estes componentes do domínio e da subordinação que distribuem seus momentos em várias combinações, a distinguir uma sociedade de outra e um acontecimento do outro, segundo as especificidades das relações de poder características de cada um (Guha, 2009, p. 36).

Desse modo, o caráter da inter-relação entre domínio e subordinação em cada caso particular dependeria do peso relativo aos elementos de coerção e persuasão no domínio, de resistência e colaboração na subordinação. Em outras palavras, da composição orgânica daquela relação de poder. A noção de hegemonia se estabelecia, assim, como "condição de domínio" na qual a persuasão se sobrepunha à coerção. Nesse sentido, o Estado colonial era considerado pelos subalternistas como "dominância sem hegemonia", no conceito lapidado por Guha (1997), contrapondo-se ao 
ponto de vista da elite comprometido com a simples noção de que o Estado colonial era genericamente o mesmo que o Estado metropolitano que o seguiu.

Como poderia um Estado constituído de cidadãos ser dito como fundamentalmente indiferente a um Estado colonial sem cidadania? O que tornava possível sustentar esse discurso elitista era a suposição de que a dominação colonial se baseava no consentimento do povo da mesma forma que a dominação da burguesia metropolitana se fundamentava no consentimento de seus "cidadãos". Uma das críticas mais importantes veiculada pelos Subaltern Studies foi no sentido de negar esse discurso hegemônico.

Interessante notar que foi o termo "elitista" - e não "hegemônico" - aquele definido como par conceitual de "subalterno" pelos Subaltern Studies. No manifesto de 1982 do grupo, intitulado On some aspects of the historiography of colonial India, o sentido do termo "subalterno" era dado por 320 Guha com referência ao dicionário de Oxford: entendido como "grau inferior", como atribuição geral para a subordinação existente na sociedade do sul da Ásia. Logo após essa definição formal, seguia-se uma referência ao projeto esboçado por Gramsci em seu Caderno 25, dedicado à história das classes subalternas. Guha afirmava nessa ocasião, prefaciando o primeiro volume da coletânea de artigos subalternistas, que embora inspirado em Gramsci, seria "indolente" equiparar o projeto "subalternista" ao projeto previsto pelo marxista italiano em suas Notes on Italian History, traduzidas para língua inglesa em $1971 .^{22}$

Tratava-se, sobretudo, de destacar a centralidade e os efeitos das relações de dominação na história colonial indiana sobre os subalternos. Embora não se pretendesse "ignorar" o dominante, uma vez que o subalterno está

22 Essa edição é composta em maior parte pelo volume III dos Quaderni del carcere, da edição crítica de Valentino Gerratana. Destacam-se nesse volume o Caderno 19 e algumas notas do Caderno 25. 
sempre sujeito à sua ação, o objetivo principal era o de retificar o viés elitista característico de grande parte das pesquisas e trabalhos acadêmicos sul-asiáticos. Esse ato de retificação nascia da convicção de que as elites haviam exercido dominância, mas não hegemonia, sobre os subalternos. Apoiados nessa noção de hegemonia e subalternidade, os intelectuais indianos concentraram-se em uma proposta metodológica para o estudo da história dos grupos subalternos e de sua relação com os dominantes. O estudo do colonialismo deveria abrir um campo de pesquisas que levasse em consideração as múltiplas diversidades da vida subalterna, especialmente no âmbito da resistência, que fosse além da extrema simplificação presente nas interpretações elitistas e nacionalistas da história indiana.

A subalternidade era entendida ainda como um contraste ao uso corrente do conceito de "classe" da época - ou seja, como efeito de relações de poder expressos por uma variedade de significados linguísticos, econômicos, sociais e culturais. O papel da cultura era fundamental nesse processo, na medida em que o projeto subalternista buscava diferenciar o uso de classe de seu sentido apenas econômico. Gramsci era relevante, portanto, pois havia elaborado com a noção de hegemonia seu par dialético de subalterno, concedendo importância definitiva aos temas da cultura e do senso comum. No caso dos subalternistas, permaneceu uma tensão na teorização sobre a noção de subalternidade. Ora visto como sujeito, como unidade na diferença, ora visto como sinônimo de povo, em sentido demasiadamente amplo, o subalterno era todo aquele que se subordinava à direção das classes dirigentes, ao mesmo tempo em que possuía um domínio da política autônomo, embora não desintegrado, dessas classes.

Foi nesse sentido que, em Elementary aspects of peasant insurgency in colonial India, Guha (1999 [1983]) abordou a historiografia da insurreição camponesa na Índia colonial. 
Movimentos camponeses estiveram presentes em formas e escalas diversas, dos conflitos locais a campanhas de "guerra", tornando-se endêmicos desde os primeiros três quartos da dominação britânica até o final do século XIX. Para o autor, as insurreições seriam necessárias antíteses do colonialismo, desde sua incipiência até o seu amadurecimento. A noção de insurreição camponesa entendida como fato "pré-político", portanto, não contribuía para entender a experiência indiana. Esses conflitos representavam a resistência à natureza da relação de dominância sem hegemonia, característica do poder colonial.

Desse modo, o projeto subalternista interveio no debate sobre nacionalismo indiano em oposição à interpretação "oficial" predominante na história moderna da Índia. Esse debate perpassou dois extremos: de um lado, os que argumentavam ser o "nacionalismo" próprio de uma pequena elite, erigida nas instituições educacionais criadas pelo governo britânico na Índia. Essa interpretação colocava em primeiro plano uma visão estreita daquilo que constituía o "interesse" político e econômico dos atores históricos, negligenciando, assim, o papel das ideologias. No outro extremo, numa vertente marxista determinista, ${ }^{23}$ a história indiana do período colonial era vista como batalha épica entre as forças do colonialismo e as do nacionalismo, sendo o primeiro uma força regressiva que distorcia todos os desenvolvimentos da sociedade e da política indiana, enquanto o segundo era uma "força regenerativa", antítese do colonialismo, que unificava e produzia um "povo indiano" mobilizado contra a Inglaterra (Chakrabarty, 2000, pp. 10-11).

23 Essa vertente marxista identifica-se, segundo aponta Chakrabarty (2000), na figura do historiador Bipan Chandra, professor da Universidade de Jawaharlal Nehru. Chandra e seus seguidores se inspiravam nos escritos marxistas e também nas teorias da dependência latino-americanas. Nessa linha de interpretação da história da Índia, Gandhi e Nehru são vistos como autores de um movimento anti-imperialista em busca da unidade da nação. 
Ambas as historiografias, consideradas elitistas, não foram descartadas dos estudos subalternistas. Guha (1982) ressaltou sua utilidade no sentido de ajudar a entender a estrutura do Estado colonial, a operação de vários órgãos em determinadas circunstâncias históricas, a natureza do alinhamento das classes que a sustentaram, alguns aspectos da ideologia dominante do período, as contradições e as complexidades das oposições mútuas e coalizões, bem como o papel desempenhado pelas personalidades britânicas e indianas mais importantes em suas organizações. O que essa historiografia não ajudava a explicar, entretanto, era o nacionalismo indiano. Sua pobreza localizava-se na compreensão da articulação das massas. Exceto, negativamente, como problema de ordem e lei, e positivamente, se possível, como resposta ao carisma de certos líderes da elite.

$\mathrm{O}$ argumento de Guha era que, paralelo ao domínio da política elitista, existiria por todo o período colonial outro domínio da política indiana no qual os principais atores não teriam sido grupos dominantes da sociedade "nativa" ou das autoridades coloniais, mas a população e a camada intermediária, tanto na cidade quanto no campo - isto é, o "povo". A coexistência desses dois domínios foi o index de uma importante verdade histórica: "a derrota da burguesia indiana ao falar para a nação" (Guha, 1982, pp. 5-6) . Aspecto importante do conflito havia sido negligenciado - o da resistência.

Contudo, é importante ter em mente que as iniciativas originadas do domínio da política subalterna não foram poderosas o bastante para desenvolver um movimento nacionalista pela libertação nacional - e o estudo dessa derrota constituiu a problemática central da historiografia colonial da Índia. Por meio dessa iniciativa, as implicações do projeto gramsciano esboçado no Caderno 25 podem ser visualizadas. A busca pela reconstituição da "história necessariamente desagregada e episódica” (Gramsci, 1975, Q25, 
§2, pp. 2283-2284) das classes subalternas indianas, tendo em vista que não obtiveram "a vitória” e que, portanto, não se apresentaram enquanto "unidade", é um ponto importante, assumido de modo criativo por Guha e por outros intelectuais indianos em seu esforço de reinterpretação da história do país.

Nessa análise, o aspecto principal pode ser apontado, como ressalta Baratta (2009), na ênfase de uma linha de substancial continuidade - nos confrontos dos subalternos na Índia - do Estado colonial ao Estado nacional liberal. Nesse sentido, a figura chave que representou o elemento decisivo de continuidade entre o velho e o novo no mundo dos subalternos consistiu na figura do "camponês". Mais que contorno social definido, pode-se entender com essa expressão uma metáfora ligada aos movimentos e às transformações demográficas que estariam em constante mudança ao redor do mundo, introduzindo elementos apa324 rentemente residuais e anacrônicos, mas que podem ser, ao contrário, decididamente inovadores e progressivos, em "pleno coração do capitalismo contemporâneo" (Baratta, 2009, p. 20).

Parte fundamental do esforço dos Subaltern Studies concentrou-se na insistência de que camponeses seriam contemporâneos ao colonialismo e parte fundamental do governo colonial estabelecido na Índia, em oposição à ideia mais comum de que seriam "anacrônicos" à modernização do mundo colonial. A tendência mais corrente na historiografia marxista global até os anos 1970 era a de olhar para as revoltas campesinas como movimentos que revelavam uma “consciência atrasada" - isso é, uma consciência que não tinha chegado aos termos da lógica institucional da modernidade ou do capitalismo (Chakrabarty, 2000, p. 13).

A historiografia indiana havia se contentado em lidar com a insurreição camponesa meramente como sujeito ou membro empírico de uma classe, mas nunca como entidade 
cuja razão constituía uma práxis chamada "insurreição". ${ }^{24}$ Essa omissão esteve presente na maior parte das narrativas através de metáforas que assimilavam as revoltas camponesas a fenômenos naturais: "estouram como trovões em um temporal, levantam como terremotos, espalham-se como incêndios e infectam como epidemias" (Guha, 1988, p. 46). Mesmo quando a historiografia se viu pressionada a produzir explicações em termos mais humanos, assumiu-se uma identidade entre natureza e cultura - marca, presumidamente, de um estado muito baixo de civilização. Desse modo, "ao camponês foi negado o reconhecimento como sujeito da história em seu próprio direito, mesmo em um projeto que era todo seu" (Guha, 1999 [1983], p. 3). O resultado, cuja responsabilidade deve ser igualmente compartilhada por todas as escolas e tendências, foi o de excluir o insurgente como sujeito de sua própria história.

Imbuído da crítica ao determinismo e ao neoidealismo realizada por Gramsci, Guha entendia que as manifestações de insurreição das classes subalternas se apresentavam de modo fragmentado e desagregado, não havendo lugar na história para a "espontaneidade" pura. A natureza da ação coletiva contra a exploração na Índia colonial se deu de forma que era necessário estender os limites imaginários da categoria "político" para muito além dos territórios demarcados pelo pensamento político europeu - era necessário historicizar a análise deste processo. Ao considerar o movimento campesino como "pré-político", e ao ignorá-lo, segundo a visão de Guha, só se poderia gerar história de um ponto de vista elitista:

24 Pela palavra "insurreição", Guha busca dar conta da consciência que informou a atividade das massas rurais conhecidas como "jacqueries", revoltas, rebeliões etc. $\mathrm{Ou}$, em suas designações indianas: dhing, bidroha, ulgulan, hool, fituri (Guha, 1999 [1983], p. 4). 
Não havia nada nos movimentos militantes das massas rurais que não fosse político. Isso dificilmente poderia ter sido de outra forma nas condições nas quais trabalhavam, viviam e conceitualizavam o mundo. Tomando o subcontinente como um todo, o desenvolvimento capitalista na agricultura permaneceu incipiente e frágil ao longo de um período de um século e meio, até 1900 (Guha, 1999 [1983], p. 6).

Mesmo que fosse válida para outros países, a noção de insurreição camponesa "pré-política" ajudava pouco a entender a experiência indiana colonial. ${ }^{25} \mathrm{O}$ elemento constante dessa relação, com toda sua variedade, era a extração do lucro do camponês por meios determinados menos pelas forças do "jogo livre" da economia de mercado do que pela força extraeconômica do proprietário de terras, presente na sociedade local e na política colonial. Tratava-se de relação de dominância e subordinação - uma relação política de tipo feudal, ou semifeudal, cujo sustento material derivava de condições pré-capitalistas de produção, e sua legitimidade de uma cultura tradicional que permanecia proeminente na superestrutura.

O Estado colonial, longe de ser neutro, era um dos elementos constitutivos dessa relação. Foi dentro do Raj que o Estado ajudou diretamente a reprodução do latifúndio. O resultado foi a revitalização da estrutura semifeudal ao transferir recursos dos membros mais antigos e menos efetivos da classe proprietária para a classe mais nova, mais dependente política e financeiramente do governo. Para o campesinato, isso significou, em muitos casos, exploração mais intensiva e sistemática: o tipo medieval de repressão, emanado da vontade arbitrária dos déspotas locais sob o

25 Neste ponto, Guha está claramente em discussão com as ideias de Hobsbawn. O material do historiador inglês é, como Guha destaca, quase inteiramente derivado da experiência europeia e daí suas generalizações não darem conta do contexto indiano. 
antigo sistema, foi substituído por uma vontade mais regulada do poder estrangeiro, que permitiu que proprietários continuassem a coletar abusivamente lucros de seus arrendatários (Guha, 1999 [1983], p. 7).

O elemento da coerção era tão explícito e ubíquo em todas as negociações com o campesinato que seria difícil ver a relação proprietário-camponês como qualquer coisa que não política. $\mathrm{O}$ camponês sabia o que estava fazendo quando se revoltava. $\mathrm{O}$ fato de que pretendia primeiramente destruir a autoridade da elite superordenada, sem projeto alternativo para sua substituição, não o colocava fora do "reino da política”. Ao contrário, Guha (1999 [1983], p. 9) insistiu no caráter político da insurreição justamente por seu caráter negativo e inversivo - "ao tentar forçar uma mútua substituição dos dominantes e dominados dentro da estrutura de poder, não deixou nenhuma dúvida sobre sua própria identidade como projeto de poder".

O historiador mostrava que os movimentos rurais eram menos primitivos do que se supunha. Na maior parte das vezes não lhes faltou nem liderança, nem objetivos, ou mesmo alguns rudimentos de um programa, embora nenhum desses atributos pudessem ser comparados com a maturidade ou a sofisticação dos movimentos historicamente mais avançados do século XX. Nenhum dos casos discutidos, entretanto, deixavam de apresentar um líder, o que se relaciona com a afirmação de Gramsci de que não há espontaneidade pura na história:

Da expressão espontaneidade se pode dar diversas definições, porque o fenômeno a que se refere é multilateral. No entanto, ocorre relevar que não existe na história espontaneidade "pura": esta coincidiria com a mecanicidade "pura". No movimento "mais espontâneo" os elementos de "direção consciente" são simplesmente incontroláveis, não deixam documento verificável. 
Pode-se dizer que o elemento da espontaneidade é, assim, característico da "história das classes subalternas", antes, dos elementos mais marginais e periféricos destas classes, que não alcançaram a consciência da classe "para si” e que portanto não suspeitam nem mesmo que a sua história possa ter qualquer importância e que deixar traços documentários tenha qualquer valor (Gramsci, 1975, Q3, §48, p. 328).

Nos movimentos analisados por Guha, é possível visualizar a "multiplicidade" de elementos marginais de "direção consciente" à qual Gramsci faz referência. Mas nenhum desses foi predominante ou superou o nível do "senso comum". Claramente não se trata, portanto, de fenômeno comparável a uma liderança partidária moderna. Uma análise com foco nesses elementos de consciência permitiu contestar a visão da experiência camponesa meramente como história de eventos, sem sujeitos. Foi com o objetivo de reabilitar esse sujeito que Guha (1999 [1983], p. 2) adotou como ponto de partida a consciência do camponês-rebelde de seu próprio mundo e sua vontade de mudá-lo.

$\mathrm{O}$ autor, portanto, buscou identificar algumas das "formas comuns e ideias gerais" da consciência camponesa insurgente ao longo do período colonial. Em Elementary aspects of peasant insurgency in colonial India (1999 [1983]), explicitou uma leitura subalternista de Marx, destacando os limites encontrados pelo capital na colônia. Daí o foco no camponês e na resistência - enfatizando a incompletude do triunfo capitalista - dentro de uma lógica de transição própria à situação colonial. A obra é uma tentativa de escapar às narrativas de modo de produção, tendo como categoria operante as relações de dominação ("elite/subalterno" ao invés de "capital/trabalho"). Observa-se, com isso, afastamento da forma marxista usual de localizar os atores em revoltas, com 
foco estritamente econômico. E nessa iniciativa, Gramsci possuiu papel central. ${ }^{26}$

As duas formulações de Guha, de que tanto o nacionalismo quanto o colonialismo tinham o objetivo de instituir na Índia um governo a serviço do capital, no qual as ideologias burguesas exerceriam "domínio sem hegemonia”, abriram o cenário movimentado em torno da persuasão como veículo de possível resistência, ao contrário da mera subordinação e coerção. Nesses termos, como já mencionamos, a hegemonia era entendida como condição orgânica e específica de dominância, na qual a persuasão sobrepõe-se à coerção (Guha, 1997, p. 23).

Assim, para Guha, a hegemonia operaria como conceito dinâmico, mantendo até a mais persuasiva estrutura da dominância, sempre e necessariamente aberta à resistência (Guha, 1997, p. 23). Para o historiador indiano, dessa forma se poderia evitar a justaposição de dominação e de hegemonia como "antinomias". Essa visão que contrapunha dominação e hegemonia, força e consenso, teria fabricado "um absurdo liberal" - a ideia de um Estado sem coerção -, a despeito do impulso fundamental de Gramsci em seu próprio trabalho (Guha, 1997, p. 23). Guha avançava, assim, ao não contrapor força e consenso - mas ao mesmo tempo restringia o alcance do conceito à específica situação na qual o consenso sobrepõe-se à força, mesmo sem anulá-la completamente.

Nesse sentido, é crucial notar que o ponto de partida dos subalternistas pode ser encontrado na insistência sobre a "autonomia da insurgência camponesa". Gramsci enfatizava a força da dominação coercitiva e da direção hegemônica exercida por grupos dominantes sobre as classes subalternas. Um de seus objetivos era justamente entender e

26 É importante destacar que há nessas análises de Guha, em menor grau, a influência do estruturalismo, nas ideias de Lévi Strauss e Durkheim, e do Maoísmo, enquanto corrente teórico-política. 
explicar porque o poder estatal, especialmente nas sociedades modernas capitalistas, parecia ser tão difícil de derrubar e porque as classes subalternas pareciam aceitar essa subordinação. O marxista italiano via poucas evidências de autonomia nos movimentos camponeses, tanto por não conseguirem se organizar e produzir seus próprios líderes, quanto num sentido mais geral, por sua incapacidade de montar um ataque ideológico e político capaz de derrubar a dominação e a hegemonia das classes dominantes. Ecoava mais uma vez um de seus valiosos argumentos metodológicos presentes no Caderno 25: "os grupos subalternos sempre sofrem a iniciativa dos grupos dominantes, mesmo quando se rebelam e insurgem: somente a vitória 'permanente' rompe, e não imediatamente, a subordinação" (Gramsci, 1975, Q25, $\S 2$, p. 2283).

Em aparente contraste com a argumentação gramsciana, Guha afirmou que, ao longo do período colonial, a política subalterna constituiu "domínio autônomo" que "não se originou da política da elite e nem sua existência dependia dela” (Guha, 1982, p. 4). Identificava esse domínio subalterno da política com ampla variedade de modos de ação e pensamento, particularmente expressados por rebeliões, revoltas e movimentos populares. Estava implícito, segundo David Arnold (2000, p. 35), que esses eram a expressão política da cultura campesina subalterna e que a visão de mundo contida era largamente autônoma daquela da elite. Guha não concluía que ambos os domínios, de domínio e subordinação, poderiam ser totalmente separados, mas ressaltava que nunca estariam totalmente integrados. Essa afirmação decorria da constatação de que "havia vastas áreas na vida e consciência do povo que nunca foram integradas à hegemonia. A estrutural dicotomia que surgiu disto é o ponto de partida da história indiana do período colonial” (Guha, 1982, pp. 5-6). 
Vale destacar que também na Argentina e no Brasil, o pensamento de Gramsci estimulou pesquisas desviantes à agenda oficial do marxismo. No continente latino-americano, o tema das classes subalternas não adquiriu centralidade como na Índia, mas o par conceitual de hegemonia e o tema dos intelectuais e da revolução passiva foram frutíferos no sentido de contrastar as visões dualistas e deterministas presentes entre comunistas dos anos 1960 e 1970.

No caso argentino, ressalta-se a experiência do coletivo editorial Pasado y Presente, fundado sob a liderança de Aricó que, com outros colaboradores da revista, foram expulsos do Partido Comunista Argentino (PCA) após a publicação do primeiro número em 1963. A expulsão se deu, segundo a síntese de Aricó - em entrevista a Horácio Crespo e Antonio Marimón - primeiramente porque a revista criticava a posição do PCA frente ao peronismo, por não ter conseguido enxergar elementos novos e necessários que a concepção política peronista introduzia, entendo-a como fenômeno de "primitivismo das massas" que podia ser liquidado com a aplicação de uma "política culta" frente às mesmas massas. Em segundo lugar, por não ter compreendido que essa atitude errônea frente ao peronismo impediu o partido de observar, ao mesmo tempo, que uma política de conquista destas massas passava necessariamente por reexame de toda a situação nacional e pela busca de um novo tipo de vinculação entre mundo intelectual e mundo proletário e popular (Aricó, 2014 [1986], p. 24).

Os intelectuais vinculados à revista gramsciana se viam em contexto intelectual marcado pela ausência de uma tradição que não estivesse associada, por um lado, às vertentes nacional-populares e, por outro, ao discurso marxista-leninista. Os primeiros se fundamentavam no argumento da "excepcionalidade" da realidade nacional e os segundos tinham no marxismo uma verdade universal, para o qual a realidade não podia ser "senão a manifestação de 
tal verdade, um mero epifenômeno" (Aricó, 2014 [1988], p. 99). Isso justificou, para Aricó, o deslumbramento com o qual ele e seus pares receberam as propostas políticas e estratégicas elaboradas pelos comunistas italianos.

Eles tinham encontrado, particularmente em Gramsci, um ponto de apoio, uma base sólida a partir da qual podiam se estabelecer sem abrir mão dos ideais socialistas. ${ }^{27}$ Ao longo dos anos 1960, argentinos gramscianos aprenderam a língua italiana, leram a obra de Gramsci e traduziram e publicaram abundante material interpretativo que chegou a eles a partir da Itália. ${ }^{28}$ Esse movimento de ideias acompanhou a observação de uma série de fenômenos que se encontravam anteriormente "fora de lugar" na esquerda argentina: a questão dos intelectuais, da cultura, da relação entre Estado, nação e sociedade e do papel do partido dentro de um bloco de forças populares.

A revista Pasado y Presente seguia, assim, um roteiro sem manuais, caracterizado pela própria experiência prática e pela conjuntura política, marcada inicialmente pelas tensões desenvolvidas em meio ao partido comunista, mas também em polêmica com as vertentes nacional-populares que tinham no peronismo sua expressão mais acabada. Gramsci lhes era útil, como foi aos subalternistas, no sentido de enfrentar as visões simplificadas acerca das atividades das camadas populares em seus movimentos políticos

27 Gramsci acompanhou, de certa forma, a invasão do neorrealismo fílmico na Argentina através de algumas publicações do Cinema Novo em especial. Aricó e seus colegas acompanharam as discussões italianas sobre estética e problemas culturais. Leram Vittorini e puderam reconstruir na Cronache di poveri amanti de Pratolini a tragédia que o fascismo significou para o mundo popular, subalterno. Traduções de Attilio Dabini lhes permitiram descobrir Carlos Levi, e seu Cristo si è fermato a Eboli lhes evocou a existência, em seu próprio país, de povos que se apegavam com dignidade a suas culturas primitivas (Aricó, 2014 [1988], p. 94).

28 Há traduções de Luporini, Della Volpe e Coletti no primeiro número da revista, de abril-junho de 1963, por exemplo, e de Togliatti e Banfi na revista $n^{\circ} 2-3$, de julho-dezembro do mesmo ano. 
contraditórios; bem como no sentido de lhes prover uma identidade desviante, mas não alheia, ao marxismo corrente. Também no Brasil, como se vê no caso da revista Presença, que articulou os principais tradutores de Gramsci no país - Carlos Nelson Coutinho, Luiz Werneck Vianna e Marco Aurélio Nogueira - a organização em torno de um coletivo editorial tinha como ponto de convergência um pedido de renovação à esquerda brasileira tomada em sua totalidade e ao Partido Comunista Brasileiro (PCB) em especial (Vianna 1983; Coutinho, 1979). A cultura então dominante nos ambientes de esquerda do país, principalmente no PCB, era fortemente influenciada pelo chamado "marxismo da III Internacional". ${ }^{29}$ Nessa tradição, o Brasil era visto como formação social atrasada, semicolonial e semifeudal, que teria necessidade de uma revolução democrático-burguesa ou de uma libertação nacional (Coutinho, 1986, p. 142).

Essa era a posição do PCB desde os anos $1930,{ }^{30}$ ao menos, mas não só (Coutinho, 1986, p. 142). Também os

29 Como explica Roberto Schwarz, o PCB teve o mérito de difundir a ligação entre imperialismo e reação interna, mas a maneira de especificá-la foi seu ponto fraco, razão do desastre futuro de 1964. Como resultante, se deu "um marxismo especializado na inviabilidade do capitalismo, e não nos caminhos da revolução”. Este marxismo, para Michael Löwy, se enquadrava numa tendência maior latino-americana, a do eurocentrismo, que concebia o continente como espécie de "Europa tropical". Combinada à tentação ao excepcionalismo indo-americano, resultava numa conclusão comum: "a de que o socialismo não está na ordem do dia na América Latina" (Löwy, 2012, p. 11). Para Schwarz, apenas na medida em que conseguiu romper com o "sistema de conciliações" então engrenado nessa perspectiva, a produção de esquerda escapou de ser "pura ideologia" (Schwarz, 2008, pp. 77-79).

30 Destaca-se o caráter pioneiro da obra de Caio Prado Jr. - para Ricupero (2000), este seria no Brasil o primeiro a realizar uma tentativa de tradução do marxismo à realidade nacional (Ricupero, 2000). Sobre a relação entre os gramscianos brasileiros e argentinos com Caio Prado Jr., vale destacar livro de Luiz Bernardo Pericás, Caio Prado Júnior: uma biografia política (2016). No capítulo "Leitores (e leituras) de Caio Prado Júnior", o autor explora inicialmente a polêmica aberta por Carlos Nelson Coutinho de que Prado Jr. não conheceria "bem o marxismo". Entre os livros encontrados na biblioteca do marxista paulistano, Pericás destaca haver os principais nomes de esquerda do século XX, dentre eles Gramsci, os intelectuais do PCB e os gramscianos argentinos. Embora ressalte a troca de cartas entre Caio Prado Jr, e Coutinho, Pericás mostra como curiosamente na obra do marxista 
que tinham escolhido o caminho da luta armada mantinham-se vinculados a essa mesma colocação geral. Existia algo, portanto, que ligava o gradualismo do PCB aos grupos de ultraesquerda: "a convicção de que o Brasil, enquanto país atrasado, deveria adotar os modelos revolucionários próprios do bolchevismo, do maoísmo ou do castrismo" (Coutinho, 1986, p. 143). Não havia a compreensão do fato de que, durante a ditadura, o país havia atingido um "nível de desenvolvimento capitalista pleno, e até mesmo de capitalismo monopolista de Estado" (Coutinho 1986, p. 143).

Não por coincidência, o declínio da ditadura e a crise da chamada "velha esquerda", de orientação terceiro-internacionalista, estiveram na raiz do grande crescimento da influência gramsciana, quando em meados da década de 1970 se deu no Brasil um fluxo de publicações de e sobre Gramsci. Bianchi (2015) destaca, nesse sentido, os estudos realizados por Vianna e Coutinho que, centrados na identidade entre via prussiana e revolução passiva, "permitiram ultrapassar os esquemas dualistas que dominavam a cultura brasileira das décadas precedentes" (Bianchi, 2015, p. 100). O conceito permitiu aos gramscianos brasileiros evidenciar o processo de modernização capitalista brasileiro em sua particularidade - "o latifúndio pré-capitalista e a dependência em face do imperialismo não revelaram obstáculos insuperáveis ao completo desenvolvimento capitalista do país" (Coutinho, 1986, p. 144).

A partir do começo dos anos 1980, os primeiros estudos brasileiros dedicados propriamente ao pensamento do marxista sardo começam a ser publicados. Esta nova dimensão dos estudos sobre Gramsci teve efeito nas interpretações do Brasil estimuladas pelo seu pensamento e permitiu melhor Agosti, com quem também se correspondeu (Pericás, 2016, pp. 63-64). 
compreensão do conceito de revolução passiva em sua especificidade (Bianchi, 2015, p. 102). Foi em meio a esse contexto que se deu a formação da revista Presença, que contava com Vianna e Coutinho entre seus principais colaboradores. Autores que, no sentido de esclarecer os "traços não clássicos" da história brasileira, recorreram à noção gramsciana de revolução passiva. ${ }^{31}$ Também na Índia, o conceito de revolução passiva foi fundamental na produção subalternista, como veremos na seção a seguir, ainda que com sentidos bastante variados.

É importante ao nosso argumento destacar justamente as distintas funções e significados que o pensamento de Gramsci assume nesses contextos, à medida em que nos remonta à hipótese de Vacca (2009) anunciada no início deste artigo. Gramsci, no contato com essas culturas nacionais, levou à formulação de projetos políticos singulares e voltados para as especificidades históricas de seus países. Consequência disso, a tradução de seus conceitos na Índia, por exemplo, foi útil ao propósito de enfrentar embates em torno do colonialismo, o que não ocorreu nos casos latino-americanos, nos quais a questão nacional se expressava a partir de outros problemas. O exercício de reinterpretação da história nacional e dos processos históricos que estavam em curso, entretanto, levou essas iniciativas intelectuais a conquistar lugar particular em meio aos marxistas de sua época.

Críticos ao marxismo oficial mobilizado pelos partidos comunistas, os gramscianos indianos, argentinos e brasileiros enfrentaram também as vertentes nacionais de esquerda mobilizadas pelo gandhismo e peronismo, e

${ }^{31}$ Coutinho, Vianna e Nogueira contribuíram à Presença com um total de trinta artigos. Para uma visão geral da revista Presença, conferir "Intelectuais e a questão da democracia no Brasil: um estudo a partir da revista Presença" (Lucca-Silveira, 2012). 
mesmo continentais, no caso do castrismo. ${ }^{32}$ Os latino-americanos tiveram que se ver, ademais, com processos de interrupção e retorno à democracia pelos quais passaram seus países. No caso indiano, de modo distinto, a atenção estava voltada ao processo de Independência, cujos elementos de continuidade com o passado colonial eram centrais às preocupações subalternistas.

É possível observar, nas diferenças mobilizadas pelos autores, que o pensamento de Gramsci lhes sugeriu reencontro frutífero com as histórias nacionais e com o próprio marxismo, de modo a destacar fragmentos de "vontade coletiva" já existentes nas práticas populares, ainda que de modo incipiente e contraditório. Por outro lado, ajudou também a revelar a ausência ou derrota da força "jacobina" nos processos de constituição dos Estados modernos, cuja forma geral de transição foi a da revolução passiva, como buscaremos mostrar adiante.

\section{Revolução Passiva}

A produção subalternista estimulou questões importantes no âmbito do marxismo indiano e, consequentemente, trouxe à tona vários problemas com a perspectiva marxista convencional sobre a "questão colonial e nacional". As ideias gramscianas acerca da modernização do Estado italiano, via conceito de revolução passiva, encontraram

\footnotetext{
${ }^{32}$ Na revista Pasado y Presente havia a intenção de buscar um clima plural de discussão de ideias políticas que não se restringia apenas aos italianos, o que fica evidente no número 4, de março de 1964, com o texto de Lukács, o qual questionava "o que é o marxismo ortodoxo?" e de Gorz, que explorava o conflito sino-soviético. No exemplar número 5-6, de abril-setembro de 1964, Sartre também aparecia entre as fontes "heterodoxas" de pensamento e a primeira presença brasileira era marcada por Arthur Gianotti. Essa presença permanece assegurada no número seguinte com um texto de Fernando Henrique Cardoso. Na revista argentina há esforço não só de tradução do marxismo italiano pensando problemas argentinos, como também com a questão latino-americana. Isto resulta não só na presença de brasileiros marxistas preocupados com questões similares na época, como também na atenção voltada ao castrismo, tema que será explorado no número 7-8, de outubro de 1964 e março de 1965.
} 
paralelo frutífero no país e animaram essa discussão. O próprio Gramsci sugerira o potencial explicativo do conceito para outros contextos:

Vincenzo Cuoco chamou de revolução passiva aquela ocorrida na Itália como resposta às guerras napoleônicas. O conceito de revolução passiva não parece exato apenas para a Itália, mas também para outros países que modernizaram o Estado por meio de uma série de reformas ou de guerras nacionais, sem passar pela revolução política de tipo radical-jacobino (Gramsci, 1975, Q4, §57, p. 504, grifos nossos).

A partir dessa formulação de Cuoco, Gramsci desenvolveu sua reflexão em diversas direções. ${ }^{33}$ Segundo demonstra Voza (2017, p. 700), através de "peculiar e complexa articulação", a noção de revolução passiva partiu dessa primeira intuição em Cuoco, depois passou a "programa político" do bloco moderado do Risorgimento, a critério de interpretação dos processos de formação dos Estados modernos (Europa-Itália) e, por fim, à forma histórica do presente e eixo portador de uma "ciência política" (Voza, 2017, p. 700).

No caso dos subalternistas, a referência a esse conceito pode ser entendida como correspondente da subalternidade, de modo a destacar a unidade histórica das classes dominantes sobre a qual também falava Gramsci em seu Caderno 25. A noção de revolução passiva permitiu revelar a forma "desde cima" através da qual foi possível dirigir e reestruturar a relação de dominação do Estado colonial

\footnotetext{
33 Segundo Bianchi (2017), Gramsci esboça ao menos três formas diferentes de revolução passiva nos Cadernos do Cárcere: "uma primeira que poderia ser chamada de francesa, uma segunda piemontesa e uma terceira americana" (Bianchi, 2017, pp. 30-31). De modo resumido, a forma francesa seria aquela em que a restauração é precedida por uma revolução; a piemontesa seria aquela em que um novo Estado é constituído, mas sem o aparato terrorista francês, ou seja, sem o fenômeno jacobino, e a americana é aquela na qual a inovação-conservação não ocorre no âmbito da política, mas das forças produtivas, como atualização do capitalismo (Bianchi, 2017, pp. 30-32).
} 
ao pós-colonial, oferecendo uma "ilusão 'transformista' da mudança no superficial de forma a garantir a continuidade de fundo" (Modonesi, 2010, p. 49).

A partir dessa visão geral, Partha Chatterjee em Nationalist thought and the colonial world, publicado pela primeira vez em 1986, aprofundava e expandia a crítica de Guha. Inspirado principalmente pelas notas gramscianas sobre o Risorgimento, em que a dimensão mais importante do conceito de revolução passiva era aquela da formação "desviante" do Estado nacional italiano, Chatterjee procurou examinar a história moderna indiana do seu ponto de vista ideológico (Chatterjee, 1998, p. 30).

Segundo Chatterjee, a concepção do Estado como "coerção mais hegemonia" e do poder como "dominação mais direção intelectual e moral" permitiu aos indianos crítica contundente às visões tradicionais de sua história. Essa crítica comportou a demonstração de que, sob condições 338 econômicas e políticas específicas a um país colonial, essa dominação necessariamente se dá sob fundações frágeis e com a manutenção de uma direção intelectual e moral fragmentada das classes dominantes frente à nova nação (Chatterjee, 1998, p. 29). De modo ainda mais específico, os escritos de Gramsci sugeriam outra linha de pesquisa que se tornou útil para o entendimento dos casos aparentemente desviantes de formação do Estado-nação capitalista, ainda que numerosos historicamente (Chatterjee, 1998, p. 29).

Nas palavras de Chatterjee, a formulação do problema era a seguinte:

Em situações nas quais faltam condições sociais para estabelecer uma hegemonia completa sobre a nova nação, a burguesia emergente recorre à 'revolução passiva', na tentativa de 'transformação molecular' das antigas classes dominantes em parceiras de um novo bloco histórico (Chatterjee, 1998, p. 30). 
O historiador considerou o caso indiano como exemplo particularmente proveitoso para utilização desse conceito e, com isso em mente, buscou traçar o panorama analítico no qual a história ideológica do Estado indiano pudesse ser estudada. O objetivo era situar, em meio ao contexto histórico da revolução passiva, "o problema da autonomia do discurso nacionalista como um discurso de poder" (Chatterjee, 1998, p. 30). Para isso, o historiador indiano lembrava o terreno teórico no qual Gramsci tinha construído seu conceito:

O conceito de revolução passiva deve ser deduzido rigorosamente de dois princípios fundamentais da ciência política: 1) que nenhuma formação social desaparece enquanto as forças produtivas que nela se desenvolveram encontram um lugar para uma ulterior formação progressiva; 2) que a sociedade não se põe tarefas para cuja solução não tenham sido criadas já as condições necessárias, etc. (Gramsci, 1975, Q15, §17, pp. 1774-1775).

Gramsci teria lançado mão dessas duas proposições marxianas do Prefácio de 1859 em suas análises dos movimentos nacionais europeus do século XIX, particularmente do Risorgimento, para chegar à identificação de dois aspectos intrinsicamente relacionados. O primeiro destacava impedimentos históricos à hegemonia burguesa, enquanto o segundo chamava atenção para possibilidades de mudança, mesmo que marginais, dentro desses limites (Chatterjee, 1998, p. 43), que se davam em termos de três momentos ou níveis de relação de força: o primeiro era o da estrutura objetiva, "independente da vontade humana", o segundo era o da relação das forças políticas e o terceiro, da relação das forças militares.

Considerando os três momentos, a conclusão à qual chegava Chatterjee era a de que nas condições estabelecidas pelo avanço capitalista no mundo, a burguesia não poderia 
esperar lançar mão de "uma 'guerra de movimento' em sentido tradicional" (Chatterjee, 1998, p. 45). Ao contrário, deveria se engajar numa "guerra de posição", um tipo de front político no qual a estratégia seria a da transformação molecular do Estado. Essa reorganização parcial do sistema se daria mediante a neutralização de adversários, conversão de antigas seções das classes dominantes em aliados e no empreendimento de reformas econômicas em escala limitada, de forma a "apropriar o apoio das massas populares, mas mantendo-as fora de qualquer forma direta de participação nos processos de governança” (Chatterjee, 1998, p. 45).

No caso indiano, Chatterjee indicava que a conformação do Estado-nação no país depois da independência tinha como "momento de partida" o encontro entre a "consciência nacionalista" e o quadro de conhecimento criado pelo pensamento racionalista pós-iluminista. Nessa ocasião, 340 aceitava-se uma diferença cultural essencial entre Ocidente e Oriente:

A cultura europeia moderna, pensa-se, possui atributos que fazem dos europeus equipados culturalmente para o poder e o progresso, enquanto tais atributos faltam nas culturas "tradicionais" do Oriente, condenando, assim, esses países à pobreza e à sujeição. Mas a reivindicação nacionalista é que esse atraso não possui um caráter que é historicamente imutável: ele pode ser transformado pela nação agindo coletivamente, ao adotar esses modernos atributos da cultura europeia (Chatterjee, 1998, pp. 50-51).

Oriente e Ocidente, nesse contexto, indicavam determinadas relações entre conjuntos de civilização. Como noções históricas, não foram construções do homem em geral, como ressaltou Gramsci, "mas das classes cultas europeias, que por meio de sua hegemonia cultural fizeram com que 
todo o mundo as aceitasse" (Gramsci, 1975, Q11, §20, p. 1419). Para tanto, afirmaram sua superioridade em termos da materialidade de sua cultura, exemplificada por sua ciência, tecnologia e pelo amor ao progresso.

Como Chatterjee adverte, combinar a modernidade considerada "verdadeira" das culturas ocidentais com a "grandeza" espiritual do Oriente configurou um programa elitista:

Da consciência popular, mergulhada em séculos de superstição e religião popular irracional, dificilmente se pode esperar que aceite este ideal: seria preciso ser transformada de fora. Este é o ambiente em que o dilema político-ideológico central ocorre em um país colonial, cuja solução, como já apresentado, se dá com a revolução passiva. Isto requer a mobilização dos elementos populares na causa de uma luta anticolonial e, ao mesmo tempo, um distanciamento daqueles elementos da estrutura do Estado. Alcança-se isto no momento de manoeuvre, um momento crucial com muitas possibilidades contraditórias. Ele combina elementos tanto da "guerra de movimento" quanto da "guerra de posição" em um processo intrínseco. Consiste numa consolidação histórica do "nacional", rebaixando o "moderno", uma preparação para a produção capitalista expandida tendo como recurso uma ideologia anticapitalista (Chatterjee, 1998, p. 51).

O pensamento nacionalista alcançaria seu completo desenvolvimento ao se tornar um discurso da ordem, da organização racional do poder. A figura política mais importante desse momento "de chegada" na Índia foi Nehru e é a partir da análise de seus textos que Chatterjee buscou identificar os principais elementos ideológicos das relações do nacionalismo em sua fase mais desenvolvida. $\mathrm{O}$ princípio político central era a autonomia do Estado, o que 
legitimou a concepção de justiça social - que não poderia ser realizada no antigo contexto "antiquado, decadente e imóvel”. Era necessário, portanto, criar um novo quadro de instituições que pudesse incorporar o espírito do progresso, ou seu sinônimo, a modernidade. Progresso ou modernidade, de acordo com os termos do século XX, significava dar primazia à esfera do econômico - a industrialização. Consequentemente, a principal tarefa política perante a nação foi a de formar um Estado nacional soberano.

O coração da reconstrução ideológica levada a cabo pelo pensamento nacionalista era, dessa forma, a constituição do Estado nacional que deveria abraçar todo o povo, dando a todos direito igual à cidadania, independentemente de sexo, língua, religião, casta, fortuna ou educação. A nação seria todo o povo, sua vitória significaria a vitória de todos, celebrando uma solidariedade nacional que incluiria inclusive a vasta massa dos camponeses. Assim como 342 na Itália analisada por Gramsci, entretanto, os camponeses na Índia eram vistos então como "ignorantes, incapazes de pensar e subordinados a excitações irracionais" (Chatterjee, 1998, p. 149).

Para controlá-los e dirigi-los dentro de um movimento nacional amplo e organizado, seria necessário manter em primeiro plano as questões agrárias no programa de mobilização. Como isso poderia ser feito se o campesinato não via como seu interesse objetivo participar na batalha por um Estado nacional unido e independente? Para isso, foi necessária a intervenção de um "gênio político" como Gandhi:

A partir de sua própria compreensão da sociedade indiana, essa emergente liderança estatal reconheceu os limites históricos de seus poderes de intervenção direta. Era uma liderança "progressista", com sua própria concepção do tipo de mudanças que eram necessárias para a sociedade indiana progredir. Identificou como obstáculo principal a 
essas mudanças a existência do Estado colonial e mirou sua substituição por um Estado nacional como o agente central da mudança. Mas sabia também que um movimento de criação de um novo Estado requeria a incorporação de uma vasta massa de camponeses à nação política (Chatterjee, 1998, p. 152).

A divisão entre os dois domínios da política - elite e classes subalternas - foi replicada na esfera do já maduro pensamento nacionalista, através do explícito reconhecimento da existência de uma divisão entre o domínio da racionalidade e o da irracionalidade, o domínio da ciência e o da fé, o domínio da organização e o da espontaneidade. A intervenção de Gandhi nesse processo foi parte necessária do progresso, própria à revolução passiva (Chatterjee, 1998, p. 155). O chamado "gandhismo" representou, portanto, um paradoxo - originalmente produto de resistência à opressão do Estado, tornou-se participante da imbricação mesma da ideologia do Estado nacional. Como no contexto analisado por Gramsci, Chatterjee demonstrou como se favoreceu a modernização capitalista à base de coalizão conservadora, em que o discurso nacionalista se completou como ideologia de Estado (Chatterjee, 1998, p. 158).

Contra esse discurso, os subalternistas endereçaram grande parte de suas pesquisas sobre a Índia colonial, empreendendo releitura de sua transição a um Estado independente. A partir do conceito de revolução passiva, como vimos, Chatterjee perpassou criticamente toda narrativa acerca da conquista da independência, denunciando o discurso nacionalista e sugerindo uma agenda de pesquisa ampla acerca dos efeitos que essa "falsa mudança" teve sobre as classes subalternas.

No caso latino-americano, Aricó (2010) lançou mão da ideia de revolução passiva, como já mencionamos, para destacar o caráter estatal das nossas formações nacionais e a 
rapidez com que as classes dominantes aqui reagiram aos movimentos de massa. No caso brasileiro, Carlos Nelson Coutinho e Werneck Vianna recorreram à noção gramsciana como forma de denunciar o caráter passivo de nosso longo processo histórico, embora tenham chegado a conclusões políticas distintas em suas análises.

Para Coutinho, as transformações políticas e a modernização econômico-social no Brasil foram sempre efetuadas "de cima para baixo", com a conservação das relações de produção atrasadas e com a reprodução da dependência ao capitalismo internacional: “essas transformações 'pelo alto' tiveram como causa e efeito principais a permanente tentativa de marginalizar as massas populares não só da vida social em geral, mas sobretudo do processo de formação das grandes decisões políticas" (Coutinho, 1979, p. 41).

A noção de revolução passiva se revelou, assim, de "inestimável" utilidade para contribuir à especificação e à análise 344 do caminho brasileiro para o capitalismo, caminho em que, como na Índia, o Estado desempenhou frequentemente o papel de protagonista (Coutinho, 1986, p. 144). Também no Brasil a transformação capitalista teve lugar graças ao acordo entre classes economicamente dominantes, à exclusão das forças populares e à utilização permanente dos aparelhos repressivos e de intervenção econômica do Estado. Segundo Coutinho, não seria difícil documentar as principais transformações "pelo alto" que tiveram lugar no país: desde a Independência ao golpe de 1964, passando pela proclamação da República e pela Revolução de 1930, todas as soluções teriam tido conteúdo elitista e antipopular (Coutinho, 1986, p. 145).

No momento em que escrevia, em fins da década de 1970 e início de 1980, essa visão da história brasileira levava Coutinho à defesa da democracia como forma de realizar uma "antirrevolução passiva". Em seu notável ensaio de 1979, "A Democracia como valor universal", o autor 
reivindicava a necessidade de que o processo de renovação democrática procedesse "de 'baixo para cima', consolidando e ampliando suas conquistas através de crescente incorporação de novos sujeitos políticos”, o que impunha às forças populares "a opção por aquilo que Gramsci chamou de 'guerra de posição”" (Coutinho, 1979, pp. 44-45). Com sua apropriação das ideias de Gramsci, Coutinho enriqueceu a defesa política da renovação democrática. ${ }^{34}$ Resolver a questão democrática significava meio de romper com o decurso da história que mantivera excluídas, até então, as classes subalternas.

Também Vianna assumiu que a modernização capitalista do Estado brasileiro se deu por meio de revolução passiva. Desde inícios da década de $1970,{ }^{35}$ o conceito gramsciano desempenhou em seu pensamento papel central. Em seu notável livro lançado em 1997, Revolução Passiva: americanismo e iberismo no Brasil, Vianna expunha alguns dos ensaios mais importantes a respeito da noção de revolução passiva em sua perspectiva. Retomando diversos aspectos de suas intervenções conjunturais - a maior parte, como também se deu com Coutinho, registrada nas páginas da revista Presença - Vianna estabelecia a particularidade de sua perspectiva.

Na sua argumentação, diferente de Coutinho, a revolução passiva brasileira possuía duas configurações distintas. A primeira era a forma de dominação das classes dominantes, na qual o transformismo se caracterizaria em sentido negativo devido à cooptação dos subalternos, cancelamento de sua identidade e aprofundamento das condições de sua dominação. Por outro lado, haveria a possibilidade de encarar a revolução passiva sem ser no cenário

\footnotetext{
34 Importante destacar que Coutinho, aqui, está imerso numa intensa influência do "marxismo italiano de 1970", das ideias difundidas pelo PCI de Togliatti, do chamado "eurocomunismo" e da tese do "valor universal da democracia" de Berlinguer.

35 Cf. Vianna 1978.
} 
das elites, passando a incorporar o elemento ativo no processo de transformismo que estava em curso. Na transição democrática essa possibilidade se reafirmaria, tendo como fermento a democracia. A expressão paradigmática, nesse caso, se manifestaria no movimento dos trabalhadores semterra (Vianna, 2004, p. 53).

A positividade expressa na revolução passiva estava na possibilidade de lhe imprimir uma dinâmica em que a mudança pudesse preponderar sobre a conservação. Dessa forma, a revolução passiva deveria ser critério de interpretação que poderia servir no sentido de mudar a chave da direção do transformismo - de negativo para positivo (Vianna, 2004, p. 105). Nessa possibilidade, estaria a "possibilidade de uma tradução do marxismo como uma teoria de transformação sem revolução 'explosiva' de tipo francês” (Vianna, 2004, p. 105).

Além de iluminar a história brasileira, a categoria 346 gramsciana desempenhou papel importante na reivindicação por uma renovação democrática nos anos de transição. Enquanto Coutinho centrou a questão democrática como estratégia política na busca por mudança do trajeto "passivo" da história brasileira, Vianna positivou a forma da "revolução passiva", abrindo a possibilidade de a mudança preponderar sobre a conservação. Também nesse caso é possível observar variedade de possibilidades abertas para a tradução do marxismo pelo pensamento gramsciano, como vimos nas demais seções do artigo.

\section{Considerações finais}

O interesse voltado à história das classes subalternas em Gramsci e a importância que esse aspecto tem em sua obra tiveram importância decisiva para o grupo dos Subaltern Studies. Não apenas como fonte para construção de uma historiografia subalterna, enquanto atividade intelectual contestatória, o pensamento de Gramsci permitiu reacender 
e enfrentar dilemas próprios da tradução do marxismo na periferia. Isso à medida em que incluiu os grupos às margens da história numa narrativa em que eram vistos como sujeitos, o que permitiu visão mais dinâmica e conflitiva da história indiana como um todo, assim como uma releitura da própria obra de Marx. Nas distâncias assumidas com o que havia elaborado Gramsci para Itália, percebemos também traços do próprio tempo. Afastados dos partidos comunistas e da atividade política institucional, Guha e os demais intelectuais subalternistas passaram prioritariamente ao debate acadêmico de ideias. Longe de considerar menos importante ou relevante, esse é um aspecto dos desafios abertos ao campo da esquerda a partir dos anos 1980, que passa por processo contraditório de fragmentação e reorganização política.

Também em outros contextos, como no caso latino-americano que destacamos neste artigo de modo subjacente, o pensamento de Gramsci serviu à criação de novos centros de elaboração cultural, nos quais a preocupação com os problemas fundamentais de cada país passou a pautar a forma como lidavam com o marxismo. Contrários à ideia de aplicação de conceitos e esquemas, criaram com isso novas interpretações, tornando-se incontornáveis para todos que buscam discutir de modo radical as possibilidades de transformação política de seus países. No caso da Índia, a interpretação da história colonial como "dominância sem hegemonia" e a busca pelos traços de autonomia das classes subalternas são exemplares nesse sentido. Ao mostrar que a tradução do marxismo é possível, mesmo aos considerados povos "sem história", o interesse no trabalho subalternista extrapola os limites do debate nacional indiano e seu conhecimento por parte de outros públicos em ambientes culturais distintos torna-se estimulante, na expectativa de que encontre novas traduções. 


\section{Camila Góes}

é doutoranda em Ciência Política pela Universidade Estadual de Campinas (Unicamp), com bolsa Fapesp. Graduou-se em Ciências Sociais na mesma universidade. Durante o mestrado em Ciência Política realizado na Universidade de São Paulo (USP), realizou estágio de pesquisa no Departamento de História da Universidade de Princeton. Como pesquisadora, atua no grupo "Pensamento e Política no Brasil" (USP) e no "Laboratório de Pensamento Político" (Unicamp).

\section{Bibliografia}

AHMAD, A. 2002. On the national and colonial questions. New Delhi:

LeftWord.

ANDERSON, P. 1992. English questions. London: Verso.

ARICÓ, J. 2010. Marx y América Latina. Buenos Aires: Fondo de Cultura Económica. 2014 [1986]. América Latina: el destino se llama democracia. In: CRESPO, H. (org.). José Aricó: entrevistas 1974-1991. Córdoba: Universidad Nacional de Córdoba. 2014 [1988]. La cola del diablo: itinerario de Gramsci en América Latina. Buenos Aires: Siglo Veintiuno.

ARNOLD, A. 2000. Gramsci and peasant subalternity in India. In:

CHATURVERDI, V. (ed.). Mapping subaltern studies and the postcolonial. London: Verso. pp. 24-49.

BARATTA, G. 2009. Prefazione. In: SCHIRRU, G. Gramsci, le culture e il mondo. Roma: Viella. pp. 9-15.

BIANCHI, A. 2010. O marxismo fora do lugar. Política E Sociedade, v. 9, n. 16, pp. 177-203.

. 2015. Gramsci interprète du Brésil. Actuel Marx, n. 57, pp. 96-111. 2016. Circulação e tradução: para uma história global do pensamento político. Paper apresentado no X Encontro da Associação Brasileira de Ciência Política, Belo Horizonte, 30 de agosto a 2 de setembro.

2017. Revolução passiva e crise de hegemonia no Brasil contemporâneo. Outubro, n. 28, pp. 27-35.

BOOTHMAN, D. 2004. Traducibilità e processi traduttivi: un caso: Antonio Gramsci linguista. Perugia: Guerra. 
BOURDIEU, P. 2002. Les conditions sociales de la circulation internationale des idées. Actes de la Recherche en Sciences Sociales, v. 145, n. 1, pp. 3-8.

CHAKRABARTY, D. 1999. Postcoloniality and the artifice of history: who speaks for "Indian" pasts? Representations, n. 37, pp. 1-26. (Edição especial: Imperial fantasies and postcolonial histories).

2000. Subaltern studies and postcolonial historiography. Views from South, v. 1, n. 1, pp. 9-32.

CHANDAVARKAR, R. 2000. The making of the working class: E. P. Thompson and Indian History. In: CHATURVEDI, V. (ed.). Mapping subaltern studies and the postcolonial. London: Verso. pp. 50-71.

CHATTERJEE, P. 1988. More on modes of power and the peasantry. In: GUHA, R.; SPIVAK, G. C. (eds.). Selected subaltern studies. New York: Oxford University. pp. 351-390. 1998 [1986]. Nationalist thought and the colonial world: a derivative discourse? Minnesota: University of Minnesota.

CHATURVEDI, V. 2000. Introduction. In: Mapping subaltern studies and the postcolonial. London: Verso. pp. 7-19.

CORTÉS, M. 2010. La traducción como búsqueda de un marxismo latinoamericano: la trayectoria intelectual de José Aricó. A

Contracorriente: Revista de Historia Social y Literatura en América Latina, v. 7, n. 3, pp. 145-167.

2015. Un nuevo marxismo para América Latina: José Aricó: traductor, editor, intelectual. Buenos Aires: Siglo Veintiuno.

COUTINHO, C. N. 1979. A democracia como valor universal. In:

SILVEIRA, E. et al. Encontros com a civilização brasileira. Rio de Janeiro: Civilização Brasileira, 1979. pp. 33-47. v. 9. 1986. As categorias de Gramsci e a realidade brasileira. Presença: Revista de Política e Cultura, n. 8.

FROSINI, F. 2003. Sulla "Traducibilità" nei quaderni di Gramsci. Critica Marxista, n. 6, pp. 29-38.

GRAMSCI, A. 1975. Quaderni del carcere. Torino: Einaudi. 2004. Escritos Políticos. Tradução de Carlos Nelson Coutinho e Luiz Sérgio Henriques. Rio de Janeiro: Civilização Brasileira.

GUHA, R. 1963. A rule of property for Bengal: an essay on the idea of permanent settlement. Paris: Mouton. 1982. On some aspects of the historiography of colonial India. In: . (ed.). Subaltern studies I: writings on South Asian history and society. Delhi: Oxford University. pp. 1-8. 
1988. The prose of counter-insurgency. In: GUHA, R.; SPIVAK,

G. C. (eds.). Selected subaltern studies. New York: Oxford University.

pp. $45-88$.

1997. Dominance without hegemony: history and power in colonial India.

Cambridge, MA: Harvard University.

1999 [1983]. Elementary aspects of peasant insurgency in colonial India.

Durham; London: Duke University.

2009. Omaggio a un maestro. In: SCHIRRU, G. (org.). Gramsci, le culture e il mondo. Roma: Viella. pp. 31-40.

HEGEL, G. 2001. A Razão na história: uma introdução geral à filosofia da história. São Paulo: Centauro.

IVES, P. R. 2004. Language and hegemony in Gramsci. London: Pluto.

KAVIRAJ, S. 1983. On the status of Marx's Writings on India. Social Scientist, v. 11, n. 9, pp. 26-46.

KAYSEL, A. 2012. Dois encontros entre o marxismo e a América Latina. São

Paulo: Hucitec.

LAL, V. 2001. Subaltern studies and its critics: debates over Indian history. History and Theory, v. 40, n. 1, pp. 135-148.

LÖWY, M. (org.). 2012. O marxismo na América Latina: uma antologia

350 de 1909 aos dias atuais. Tradução de Cláudia Schilling e Luís Carlos

Borges. 3. ed. São Paulo: Fundação Perseu Abramo.

LUCCA-SILVEIRA, M. P. 2012. Intelectuais e a questão da democracia no

Brasil: um estudo a partir da revista Presença. Dissertação de Mestrado em

Ciência Política. São Paulo: FFLCH, USP.

MARX, K. 1978. Sobre o colonialismo. Tradução de Fernanda Barão.

Lisboa: Estampa.

MEALLA, L. T. 2002. La producción del conocimiento local: historia y política en la obra de René Zavaleta. La Paz: Muela del Diablo.

MODONESI, M. 2010. Subalternidad, antagonismo, autonomía: marxismo y

subjetivación política. Buenos Aires: Clacso; Prometeo Libros.

MORSE, R. 2000. O Espelho de Próspero: cultura e ideias nas Américas.

Tradução de Paulo Neves. São Paulo: Companhia das Letras.

PERICÁS, L. B. 2010. José Carlos Mariátegui e o Brasil. Estudos Avançados,

São Paulo, v. 24, n. 68, pp. 335-361.

2016. Caio Prado Júnior: uma biografia política. São Paulo: Boitempo.

PORTANTIERO, J. C. 1977. Los usos de Gramsci: Cuadernos de Pasado y

Presente, n. 54. Cerro del Agua: Siglo Veintiuno.

RICUPERO, B. 2000. Caio Prado Jr. e a nacionalização do marxismo no Brasil.

São Paulo: Editora 34. 
SCHWARZ, R. 2008. Cultura e política, 1964-1969. In: O pai de família e outros estudos. São Paulo: Companhia das Letras. pp. 70-111. SCOTT, J. 1999. Foreword. In: GUHA, R. (ed.). Elementary aspects of peasant insurgency in colonial India. Delhi: Oxford University. pp. 4-14.

SKINNER, Q. 1969. Meaning and understanding in the history of ideas. History and Theory, v. 8, n. 1, pp. 5-53.

SPIVAK, G. 1988. Subaltern studies: deconstructing historiography. In: GUHA, R.; SPIVAK, G. (eds.). Selected subaltern studies. New York: Oxford University. pp. 3-33.

SUBRAHMANYAM, S. 2004. Prefácio. In: CHATTERJEE, P. Colonialismo, modernidade e política. Salvador: Edufba. pp. 7-14.

TARCUS, H. 2007. Marx en la Argentina: sus primeros lectores obreros, intelectuales y científicos. Buenos Aires: Siglo Veintiuno.

THOMPSON, E. 1926. The other side of the medal. New York: Harcourt, Brace and Company.

TOSEL, A. 1981. Filosofia marxista e traducibilità dei linguaggi e delle pratiche. In: BACZKO, B. et al. (eds.). Filosofia e politica: scritti dedicati a Cesare Luporini. Firenze: La Nuova Italia.

VACCA, G. 2009. Prefazione. In: SCHIRRU, G. (org.) Gramsci, le culture e il mondo. Roma: Viella. pp. 9-15.

VIANNA, L. W. 1978. Liberalismo e sindicato no Brasil. 2. ed. Rio de Janeiro: Paz e Terra. . 1983. Problemas de política e de organização dos intelectuais.

Presença-Revista de Política e Cultura, n. 1. 2004. A revolução passiva: iberismo e americanismo no Brasil. 2. ed. Rio de Janeiro: Revan.

VOZA, P. 2017. Revolução passiva. In: LIGUORI, G.; VOZA, P. Dicionário Gramsciano. São Paulo: Boitempo. 


\section{D)}

\section{DILEMAS DA TRADUÇÃO DO MARXISMO NA PERIFERIA: ANTONIO GRAMSCI E OS FUNDAMENTOS DOS SUBALTERN STUDIES}

\section{CAMILA GÓES}

Resumo: Este artigo busca analisar os usos realizados do pensamento de Antonio Gramsci na Índia com Subaltern Studies. Detemo-nos, com maior ênfase, à análise da primeira fase do grupo, ao longo dos anos 1980, marcada pela influência do pensamento gramsciano e pela liderança do historiador Ranajit Guha. A proposta consiste em situar a discussão subalternista no âmbito da circulação das ideias de Gramsci em contextos periféricos, adotando como contraponto o caso latino-americano, em particular através da produção dos gramscianos argentinos e brasileiros. Além de incidir no específico objetivo de destacar a internacionalização das ideias do marxista italiano, buscaremos examinar, de modo subjacente, a forma como a própria obra de Marx foi repensada nesses contextos a partir da influência gramsciana, tendo como hipótese tratar de tentativas de tradução do marxismo para a periferia do capitalismo. Buscamos demonstrar essa hipótese através da análise pormenorizada das teses subalternistas, bem como sugerir pontos de encontro com latino-americanos, em especial àqueles vinculados às revistas Pasado y Presente e Presença.

Palavras-chave: Subaltern Studies; Gramsci; Tradução; Marxismo.

\section{DILEMIMAS OF MARXISM TRANSLATION IN THE PERIPHERY: GRAMSCI AND THE FOUNDATIONS OF SUBALTERN STUDIES}

Abstract: In this article, we seek to analyze the uses of Antonio Gramsci's thought about India with Subaltern Studies. We will focus on the analysis of the group's first phase, throughout the 1980s, influenced by Gramscian thought and the leadership of the 
historian Ranajit Guha. Our objective is to situate subalternist discussion within the context of Gramsci's ideas dissemination in peripheral contexts, adopting as counterpoint the Latin American case, in particular through the production of Argentine and Brazilian Gramscian followers. In addition to focusing on highlighting the internationalization of the Italian Marxist ideas, we seek to examine, in an underlying way, how Marx's own work was rethought in these contexts from Gramsci's influence, with the hypothesis of being attempts of Marxism translation to the periphery of capitalism. We tried to demonstrate this hypothesis through detailed analysis of subalternist theses, as well as to suggest meeting places with Latin Americans, especially those linked to the 'Pasado y Presente' and 'Presença' journals.

Keywords: Subaltern Studies; Gramsci; Translation; Marxism.

Recebido: 07/07/2015 Aprovado: 04/09/2017 